\title{
Action-related information trumps system information: influencing consumers' intention to reduce food waste
}

Article

Accepted Version

Creative Commons: Attribution-Noncommercial-No Derivative Works 4.0

Neubig, C. M., Vranken, L., Roosen, J., Grasso, S., Hieke, S., Knoepfle, S., Macready, A. L. ORCID: https://orcid.org/00000003-0368-9336 and Masento, N. A. ORCID:

https://orcid.org/0000-0003-2881-1887 (2020) Action-related information trumps system information: influencing consumers' intention to reduce food waste. Journal of Cleaner Production, 261. 121126. ISSN 0959-6526 doi:

https://doi.org/10.1016/j.jclepro.2020.121126 Available at https://centaur.reading.ac.uk/89601/

It is advisable to refer to the publisher's version if you intend to cite from the work. See Guidance on citing.

To link to this article DOI: http://dx.doi.org/10.1016/j.jclepro.2020.121126

Publisher: Elsevier

All outputs in CentAUR are protected by Intellectual Property Rights law, including copyright law. Copyright and IPR is retained by the creators or other copyright holders. Terms and conditions for use of this material are defined in the End User Agreement. 


\section{www.reading.ac.uk/centaur}

\section{CentAUR}

Central Archive at the University of Reading

Reading's research outputs online 


\section{Journal Pre-proof}

Action-related information trumps system information: Influencing consumers' intention to reduce food waste

Christina M. Neubig, Liesbet Vranken, Jutta Roosen, Simona Grasso, Sophie Hieke, Sandra Knoepfle, Anna L. Macready, Natalie A. Masento

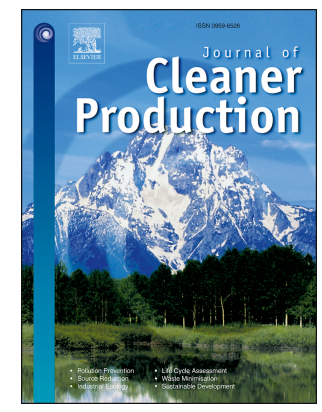

PII: S0959-6526(20)31173-2

DOI: https://doi.org/10.1016/j.jclepro.2020.121126

Reference: JCLP 121126

To appear in: Journal of Cleaner Production

Received Date: 19 December 2019

Revised Date: 12 March 2020

Accepted Date: 14 March 2020

Please cite this article as: Neubig CM, Vranken L, Roosen J, Grasso S, Hieke S, Knoepfle S, Macready AL, Masento NA, Action-related information trumps system information: Influencing consumers' intention to reduce food waste, Journal of Cleaner Production (2020), doi: https://doi.org/10.1016/ j.jclepro.2020.121126.

This is a PDF file of an article that has undergone enhancements after acceptance, such as the addition of a cover page and metadata, and formatting for readability, but it is not yet the definitive version of record. This version will undergo additional copyediting, typesetting and review before it is published in its final form, but we are providing this version to give early visibility of the article. Please note that, during the production process, errors may be discovered which could affect the content, and all legal disclaimers that apply to the journal pertain.

(C) 2020 Published by Elsevier Ltd. 


\section{Author Contributions}

Neubig developed hypotheses, analyzed data and wrote the original draft. Knoepfle participated in preliminary data analysis. Macready, Roosen and Vranken helped to review and edit the paper. All helped to develop the questionnaire. Hieke, Macready, Roosen and Vranken were responsible in conceptualizing the study. 


\section{Action-related information trumps system information: Influencing consumers' intention to reduce food waste}

Christina M. Neubig ${ }^{\mathrm{a}^{*}}$, Liesbet Vranken ${ }^{\mathrm{b}}$, Jutta Roosen $^{\mathrm{a}}$, Simona Grasso ${ }^{\mathrm{c}}$, Sophie Hieke ${ }^{\mathrm{d}}$, Sandra Knoepfle ${ }^{\mathrm{a}}$, Anna L. Macready ${ }^{\mathrm{c}}$, Natalie A. Masento ${ }^{\mathrm{e}}$

${ }^{a}$ Technical University of Munich, TUM School of Management, Chair of Marketing and Consumer Research, Alte Akademie 16, 85354 Freising, Germany

${ }^{\mathrm{b}}$ KU Leuven, Division of Bioeconomics, Celestijnenlaan 200e - box 2411, 3001 Leuven, Belgium

${ }^{\mathrm{c}}$ School of Agriculture, Policy and Development, University of Reading, Reading RG6 6AR, UK

${ }^{\mathrm{d}}$ European Food Information Council, Rue des Deux Eglises 14, 1000 Brussels, Belgium

${ }^{\mathrm{e}}$ Department of Food and Nutritional Sciences, University of Reading, Reading RG6 6AP, UK

*Corresponding author: christina.neubig@tum.de (C.M. Neubig)

\section{Author Contributions}

Neubig developed hypotheses, analyzed data and wrote the original draft. Knoepfle participated in preliminary data analysis. Macready, Roosen and Vranken helped to review and edit the paper. All helped to develop the questionnaire. Hieke, Macready, Roosen and Vranken were responsible in conceptualizing the study.

\section{Acknowledgements}

Funding: This work was supported by the European Institute of Innovation and Technology (EIT) through KIC Food [Project 18066 “Don’t Be a Food Waster”, 2018].

The authors would like to thank all other members of the EIT "Don't be a food waster" project for their inspirational counsel and support during the project: Camila Massri, Esereosa Omoarukhe, Margot Van Cauter and Tjitske Anna Zwart. Moreover, the authors would like to thank Kirstyn Byrne from EUFIC for the appealing graphical design of the information that was provided to the treatment groups. 
1 Action-related information trumps system information: Influencing

2 consumers' intention to reduce food waste

3

4

5

6

7

\begin{abstract}
In order to substantially reduce food waste at the household level, it is essential to change consumer behavior. Informing consumers about the food waste issue is a promising means of bringing about behavior change: research confirms that information can increase food waste reduction behavior. However, it has yet to be determined what kind of information is most effective and exactly how that information affects consumer food waste behavior. This study compares the effects of system vs. action-related information (i.e., knowing what impacts specific actions entail vs. knowing how specific actions can help to accomplish a goal) on behavioral intention towards food waste. That is, the study focuses on the effect of information on the role of food waste in the food system versus information of actions that can be taken to avoid it. Moreover, an adapted model of the Theory of Planned Behavior is used to assess how these information effects are mediated by consumers' attitude, norms, and perceived behavioral control. Results from an online experiment with a between-subjects design $(\mathrm{N}=2,248)$ show that action-related information significantly increases respondents' intention to reduce food waste while system information has no significant effect. The change in behavioral intention in the action-related information group is ascribed to greater personal norm activation, more favorable attitudes towards food waste reduction, and higher perceived behavioral control of food waste behaviors. Even though system information does not significantly increase intention to reduce food waste, it results in more favorable attitudes towards food waste reduction. The findings provide insights for policy makers and NGOs on what type of information to consider when designing effective food waste reduction campaigns targeted at consumers, with action-related information supporting the opportunity for consumer behavior change.
\end{abstract}

Keywords: Food Waste; Theory of Planned Behavior; Consumer Behavior; System Knowledge; Action-related Knowledge; Information Experiment

Word count: 9,351 (excluding Appendix) $\rightarrow$ before revision: 10,659 


\section{Introduction}

The Food and Agricultural Organization of the United Nations estimates that a third of all food produced globally for human consumption is wasted (FAO, 2011). Food waste is defined as “...food appropriate for human consumption being discarded, whether or not after it is kept beyond its expiry date or left to spoil. Often this is because food has spoiled but it can be for other reasons such as oversupply due to markets, or individual consumer shopping/eating habits." (FAO, 2013: 9). ${ }^{1}$ In industrialized countries, the lion's share of food waste is attributed to the consumption stage of the supply chain: Private households are responsible for more than half of total food waste in Europe (Stenmarck et al., 2016). To reduce food waste one should avoid the generation of surpluses that get thrown away or give surpluses to those who are in need. While information and communication technologies based sharing economy platforms enable the rise of collaborative consumption, an attitude behavior gap might loom in the sharing economy (Hamari et al., 2016). Therefore, a primary way to reduce food waste remains avoiding the generation of food surpluses.

Consumer food waste generation and prevention has gained increasing scientific attention in recent years and many determinants of consumer food waste behavior have been discussed (e.g., Diaz-Ruiz et al., 2018). However, when it comes to understanding how knowledge may influence consumer food waste behavior, research is still limited and findings lack consensus. While some studies confirm the importance of knowledge in food waste behavior (e.g., Graham-Rowe et al., 2014), others find no effect (e.g., Visschers et al., 2016). In addition to exploring how existing knowledge affects consumer food waste behavior, research has started to investigate the effect of newly acquired knowledge, for instance through education or provision of information (e.g., Liz Martins et al., 2016). Remarkably, most studies (e.g., Schmidt, 2016) focus on what Frick et al. (2004) termed action-related knowledge (i.e., knowledge about practices that help to reduce food waste at home). The effect of system knowledge (i.e., knowledge related to the impact of food waste) on the other hand is rarely studied. The lack of focus on system knowledge in this research area is surprising, especially in view of current food waste reduction measures such as food waste information campaigns that often stress the environmental and financial impacts of food waste in addition to providing practical tips and information. Therefore, exploring how consumers perceive this kind of information and whether it can promote changes in their behavior is highly relevant.

\footnotetext{
${ }^{1}$ Even though there are several methods to recycle discarded food (e.g., Maroušek et al., 2013) and it is advised to turn waste into compost if one does end up wasting some food (Monier et al., 2010), it is important to note that according to this definition, recycled or composted food would still be regarded as food waste.
} 
Furthermore, for the design of effective food waste reduction campaigns in the future, it is essential to understand which is more effective - food waste system knowledge vs. food waste action-related knowledge.

\subsection{The Theory of Planned Behavior in Food Waste Research}

The Theory of Planned Behavior (TPB) (Ajzen, 1991) postulates that behavior is directly predicted by behavioral intention. Behavioral intention, in turn, is determined by attitude, subjective norm, and perceived behavioral control (PBC). An attitude towards a specific behavior reflects a person's positive or negative evaluations of that behavior. The subjective norm entails the social pressure to (dis)engage in a certain behavior (i.e., the feeling that important people, such as friends and family, would approve or disapprove of a certain behavior). Finally, PBC describes the degree to which a person feels capable of performing a specific behavior. In addition to influencing behavioral intention, PBC may also directly influence the behavior itself.

Applied in the context of food waste behavior, this means that intention to reduce food waste should be higher if a person has a positive attitude towards reducing food waste, thinks that his/her peers would approve of him/her reducing food waste, and feels that reducing food waste is within his/her capabilities. A higher intention to reduce food waste is in turn associated with a greater likelihood of performing food waste reduction behavior. Several studies have supported these assumptions with a significant influence of all three constructs (attitude, subjective norm, PBC) on intention (Graham-Rowe et al., 2015), while other studies report no association between either subjective norm (Visschers et al., 2016), PBC (Stancu et al., 2016) or attitude (Russell et al., 2017) and consumers' behavioral intention.

Even though the TPB has been accepted as an adequate model to predict food waste behavior, it still does not capture some important food waste drivers such as self-identity or anticipated regret (Graham-Rowe et al., 2015). Therefore, previous research (e.g., Stancu et al., 2016) has attempted to extend and adapt the TPB to account for previously overlooked drivers of food waste behaviors. One construct frequently added by researchers to the TPB model is personal norm - a term interchangeably used in literature and replaced by terms such as moral attitudes (Stefan et al., 2013) or moral norm (Stancu et al., 2016). Personal norm refers to the "moral obligation felt by the individual to follow the line of behavior in question" (Schwartz, 1973: 353). Compared to subjective norms, where behavior is externally motivated by expected 
approval or disapproval by others, people comply with personal norms for internal reasons such as expectations about self-administered rewards and punishment and anticipated emotions such as guilt and pride (Schwartz, 1973). Studies that included a personal norm construct in their models find that it significantly influences behavioral intention (e.g., van der Werf et al., 2019; Visschers et al., 2016) with some even reporting personal norms to have the greatest impact on intention (Lorenz et al., 2017a; Pakpour et al., 2014) ${ }^{2}$. Yet, in other studies, personal norms have no significant influence on behavioral intention (Stancu et al., 2016) or the construct is not included in the final model (Graham-Rowe et al., 2015) ${ }^{3}$.

In addition to personal norms, researchers have included a number of other additional constructs in their TPB models such as taste perception (Lorenz et al., 2017a), perceived portion size (Lorenz et al., 2017b), the "concept of wanting to be a good provider" (Visschers et al., 2016: 69), self-identity and anticipated regret (Graham-Rowe et al., 2015), routines (Stancu et al., 2016), as well as habits and emotions (Russell et al., 2017). Those extended TPB models have been able to explain between $29 \%$ and $74 \%$ of the variance in food waste intention, and between $16 \%$ and $46 \%$ of the variance in food waste behavior.

\subsection{Information, Knowledge and Food Waste}

This paper focuses on consumers' objective knowledge, which is defined as what an individual actually knows, meaning information that is stored in memory (Brucks, 1985). Frick et al. (2004) divided objective environmental knowledge into three dimensions, namely system knowledge (knowing what), action-related knowledge (knowing how) and effectiveness knowledge (knowing when and why). System knowledge includes basic scientific knowledge such as knowledge about the functioning of ecosystems and the processes within them (Schahn and Holzer, 1990) as well as knowledge about corresponding environmental problems and their consequences (Hines et al., 1987). Action-related and effectiveness knowledge are closely linked: Action-related knowledge comprises possible courses of action and solutions for environmental issues (Ernst, 1994) while effectiveness knowledge additionally addresses the effectiveness associated with a particular behavior (e.g., the ecological benefit of various behavioral alternatives). In order to achieve the greatest

\footnotetext{
${ }^{2}$ Pakpour et al. (2014) do not use the term personal norm, but their construct "moral obligation" is comparable to the operationalization of personal norm in other studies.

${ }^{3}$ In the study of Graham-Rowe et al. (2015), moral norm was not included in the final model due to high correlations with self-identity and anticipated guilt. The authors assume that there might be an empirical overlap between those three constructs.
} 
environmental benefit (effectiveness knowledge), it is essential to be aware of environmental problems and understand the basic characteristics of an environmental system (system knowledge) as well as to know how to take action (action-related knowledge) (Frick et al., 2004; Kaiser and Fuhrer, 2003).

Only a few studies have looked into consumers' objective knowledge about food waste, and those who did so found it to be rather limited. For instance, when thinking about food waste, consumers do not usually think of food parts such as vegetable peelings as contributing to waste (Exodus Market Research, 2007). Consequently, consumers tend to think that they are merely discarding inedible parts of their food and that most of their food waste is unavoidable (Richter, 2017). Generally, consumers are unaware of the fact that they are the main generators of food waste within the food system and the common perception is that agriculture and retailers are mainly responsible for food waste (Díaz-Ruiz et al., 2015).

Moreover, Brook Lyndhurst et al. (2007) found that consumers predominantly consider food waste as an economic problem rather than a social or environmental one. This is confirmed by Watson and Meah (2012), whose participants barely saw the link between food waste and environmental issues such as greenhouse gas emissions in a qualitative study. The lack of knowledge with regard to environmental consequences of food waste was further highlighted by studies showing that consumers felt that food waste has no negative impact on the environment as it is biodegradable and rots down (e.g., Graham-Rowe et al., 2014). Furthermore, research shows that consumers are not concerned about food waste when it is composted (Neff et al., 2015) and that they perceive discarded packaging as being a bigger environmental problem than food waste (Brook Lyndhurst et al., 2007).

While several studies confirm a lack of food waste knowledge, previous research has also shown that consumers who do have such knowledge might actually waste less. For instance, in an exploratory study using food waste diaries, Williams et al. (2012) found that households who had previously participated in an environmental education program waste less food compared to households who had not participated in such a program. In a qualitative study, Graham-Rowe et al. (2014) confirmed that consumers, who feel knowledgeable in relation to food management, report that their skills and knowledge help them to minimize food waste in their homes. Moreover, based on findings from a mixed-method study (interviews and participant observations) by Farr-Wharton et al. (2014), knowledge on how to creatively use food when cooking meals directly influences food waste behavior. In addition, supply knowledge (knowing what food consumers have available) and location knowledge (knowing 
where to locate food items) were identified as being directly related to food waste. Therefore, increasing consumers' food waste knowledge by providing additional information seems a promising measure for reducing household food waste. Governments as well as nongovernmental organizations (NGOs) have already adopted this approach by initiating information-based campaigns (e.g., "Love Food, Hate Waste" in the UK; "Zu gut für die Tonne" [Too good for the bin] in Germany).

\subsection{Objectives and Theoretical Model}

Several studies confirm that education/information campaigns can be effective in reducing household food waste (Reynolds et al., 2019). The present study extends this line of research by investigating how different types of knowledge (i.e., system vs. action-related knowledge) affect consumer food waste behavioral intention and which type is more effective in reducing it. Knowledge, however, is a behavior-distal factor: rather than influencing behavior directly, the effect of knowledge on behavior has been found to be mediated and conveyed by behavior-proximal factors such as attitude, personal norms, and intention (Kaiser and Fuhrer, 2003). Therefore, this study intends to connect knowledge to the constructs of the TPB. An adaption of the TPB was used to assess consumers' attitude, norms, and PBC, and to relate those constructs to behavioral intention towards food waste reduction. This study aims at answering the following three research questions:

(1) What do consumers think and know about food waste? More precisely, this study aims at measuring consumers' attitudes, norms, PBC, and intentions regarding food waste reduction as well as their general, system, and action-related food waste knowledge.

(2) What is the effect of additional information on consumers' intention to reduce food waste, as well as their attitude, norms, and PBC? More precisely, this study aims at investigating if there is a general information effect and, if so, which kind of information (system vs. actionrelated) is more effective in increasing intention to reduce food waste. To this end, additional food waste information was developed using a novel gamification approach (i.e., a food waste quiz). By this means, information was provided using active learning methods as opposed to passive learning methods that require respondents to simply read the provided information.

(3) Is an adaption of the TPB a suitable theoretical model to reflect consumer food waste behavior and do the TPB constructs (attitudes, norms, PBC) mediate the hypothesized information effect on intention to reduce food waste? 
Following the TPB, it was hypothesized that intention to reduce food waste is predicted by attitude towards reducing food waste, subjective norm and PBC. As suggested by previous research (e.g., Visschers et al., 2016), the model was extended to include the personal norm construct. Figure 1 shows the model that was specified for the present study. Knowledge per se was not included in the theoretical model, however multiple participant groups received different types of information in order to compare information effects. In line with previous findings (e.g., Williams et al., 2012), it was expected that more informed respondents have a higher intention to reduce food waste.

While it was assumed that both system and action-related information result in a higher intention to reduce food waste, the process is likely to be different for each type of information. System information was presumed to make respondents aware of the severe consequences of their food waste (environmental, social, and financial). A change in their behavioral intention was therefore expected to trace back to an increased personal norm activation and more favorable attitudes towards food waste reduction. On the other hand, action-related information was presumed to strengthen consumers' beliefs about their capability or control over reducing food waste at home. A change in their behavioral intention was therefore expected to be associated with an increase in respondents' PBC. In addition, increased control belief strength may lead to more favorable attitudes towards food waste reduction. Therefore, action-related information may additionally increase behavioral intention via respondents' attitude.

This study contributes to the growing body of food waste literature and provides information on how to tackle the serious issue of consumer food waste. First, it extends previous research concerning consumers' attitudes, norms, $\mathrm{PBC}$ and intention towards food waste reduction. Moreover, new insights into consumers' (lack of) food waste knowledge are provided which are important when considering how to tackle consumer food waste. Second, the study contributes important findings on how increased knowledge can affect consumers' willingness to reduce food waste at home. This study provides insights into what kind of information is more effective in changing consumers' intention to reduce food waste and how this effect is mediated by attitude, norms, and PBC. These findings can inform public policy and help NGOs and policy-makers to design more effective information campaigns targeting consumer food waste reduction. Third, this study adds to the current debate around the suitability of the TBP and extended TBP models in food waste research as it provides 
227

evidence that the TBP (and its extended version) can offer a meaningful framework in studying and understanding drivers for consumer food waste behavior.

\section{Material and Methods}

\subsection{Procedure and Sample}

Data was collected through an online survey in Belgium (Flanders), Germany, and the UK. The three countries were selected based on the amount of food waste they produce: the UK and Germany are the two European countries with the highest total amount of food waste. Belgium, in turn, is the third most wasteful country in Europe (after the Netherlands and Cyprus) considering per capita food waste (Monier et al., 2010). Data collection took place in June and July 2018. A total of 2,250 respondents older than 18 years were recruited via a market research firm. Respondents were split equally across the three participating countries (750 respondents per country). The average response rate was $22 \%$. Respondents who reported to have randomly clicked through the questionnaire $(.09 \%)$ were excluded from the analysis. This resulted in a final dataset of 2,248 respondents (748 from Belgium, 750 from Germany, 750 from the UK).

The sample was $51 \%$ female, $49 \%$ male. The mean age was 49 years $(\mathrm{SD}=16.75)$. Almost $60 \%$ of the sample held a university degree (Bachelor, Master, $\mathrm{PhD}$ ) or vocation/technical degree. Most respondents lived in a two-person household (41\%), followed by single (28\%), three-person (16\%) and four-person (10\%) households. Less than 5\% of the sample lived in a household with five or more persons. Almost all of the respondents stated that they have at least some responsibility for food shopping (99\%) and preparation/cooking (94\%). Details about the socio-demographic characteristics of the study's sample by country and treatment group are depicted in the Appendix, Table A1.

The sample is representative for the respective countries regarding age, gender, monthly net income, employment status and household composition. There are slight deviations regarding education (respondents in this study's sample reported higher education than the representative numbers for the respective countries). 
257

The survey was categorized into socio-demographic questions, questions informed by the constructs of the TPB, and a food waste knowledge quiz ${ }^{4}$. The items for the TPB questions were developed based on previous studies. A 3-item scale asking about respondents' intention to reduce food waste was adapted from Stancu et al. (2016). Respondents were asked whether they intend, whether their goal is, and whether they will try to reduce the amount of food they throw away. Respondents answered on a 7-point Likert scale where 1 indicated strongly disagree and 7 indicated strongly agree. To assess subjective and personal norms, items were developed based on Thøgersen (2006): Two items measured subjective and two items measured personal norms, the latter with a focus on the feeling of guilt. For all four norm variables, respondents had to indicate their level of agreement to the given statement on a 5point Likert scale where 1 indicated strongly disagree and 5 indicated strongly agree. Attitude was assessed by asking participants to respond to the statement "In my opinion, reducing food waste is..." on two pairs of unipolar scales for positivity ( 1 indicated not at all positive and 7 indicated extremely positive) and importance ( 1 indicated not at all important and 7 indicated extremely important). The attitude items were developed based on Stancu et al. (2016). The wordings and scales were slightly adapted. PBC was measured on a 3-item scale adapted from Russell et al. (2017). Respondents had to consider whether it is mostly up to them to reduce food waste in their home, how much control they have over reducing food waste in their household and how difficult it would be for them to reduce food waste at home. All PBC items were measured on a 5-point Likert scale where 1 indicated strongly disagree and 5 indicated strongly agree. An overview of all TPB questions asked and the respective sources are shown in the Appendix, Table A2.

The knowledge quiz included a total of 13 questions. While some of the questions were based on previous food waste research findings, others were informed by the World Wildlife Fund (2018) food waste quiz ${ }^{5}$. In the end, the quiz included three types of food waste questions: (1) general food waste questions (e.g., food waste statistics), (2) system knowledge questions (e.g., environmental impact of food waste), and (3) action-related knowledge questions (e.g.,

\footnotetext{
${ }^{4}$ Data used for this research was collected within a broader consumer survey that measured a number of additional variables as well. However, those were not relevant for the purpose of this study and are therefore not described here. The full questionnaire is available upon request.

${ }^{5}$ The quiz can be found at https://www.worldwildlife.org/pages/take-the-food-waste-quiz. The idea of passing food waste knowledge through a quiz was used to assess the effect of different types of knowledge, which has not been tested in literature before.
} 
correct storage of food products). An overview of the quiz questions is provided in the Appendix, Table A3.

Respondents were randomly assigned to one of four groups including two control (C1 and $\mathrm{C} 2$ ) and two treatment groups (T1 and T2) with an equal distribution of age and gender between the groups. In order to determine effects of food waste knowledge on behavioral intention, $\mathrm{T} 1, \mathrm{~T} 2$, and $\mathrm{C} 1$ respondents took the food waste quiz midway through the questionnaire, i.e., before responding to the questions on norms, attitude, PBC, and intention. $\mathrm{T} 1$ took the general and system knowledge quiz, receiving instant feedback including the correct answers and further information on each question topic. T2 took the general and action-related knowledge quiz, also receiving instant feedback including the correct answers and further information on each question topic. $\mathrm{C} 1$ took the general and system knowledge quiz but did not receive any feedback. To test for a mere quiz/gamification effect, $\mathrm{C} 2$ took the whole quiz (all questions) at the end of the questionnaire and also received no feedback. To ensure everyone had the same understanding of the term 'food waste', respondents were given a comprehensive definition following Parfitt et al. (2010) prior to receiving the TPB questions. For groups T1, T2, and C1, this definition was provided between the second and third quiz question ${ }^{6}$. $\mathrm{C} 2$ was simply provided with the definition before answering the TPB questions. A flow chart of the questionnaire design is presented in the Appendix, Figure A1. Examples of the food waste information and definition provided to respondents is depicted in the Appendix, Figures A2, A3 and A4.

\subsection{Data Analysis}

First, a descriptive analysis of the TPB constructs and consumers' knowledge was conducted using IBM SPSS Statistics 25. As the variables attitude, personal norm, subjective norm, PBC and behavioral intention were measured on multi-item scales, internal reliability of these scales was analyzed via confirmatory factor analysis in SPSS Amos 25. Factor scores were calculated and used for further analyses. The knowledge level of respondents was analyzed by calculating the percentage of correct answers per question and the distribution of responses across the knowledge categories. To test the effect of provision of food waste information on

\footnotetext{
${ }^{6}$ The definition was provided only after asking the first two questions since it might have influenced respondents' answers to the initial and fairly general food waste questions. For the following questions, however, it was necessary to establish a common understanding of the term.
} 
the TPB constructs, factor scores were compared between groups using t-tests and analyses of variance (ANOVA).

Next, covariance-based structural equation modelling using SPSS Amos 25 was carried out in order to estimate the hypothesized model using maximum likelihood estimation. Before interpreting the relationships in the model, goodness-of-fit was assessed. Since there is no consensus in the literature on which goodness-of-fit indicator best predicts model fit, several indicators $(\chi 2$, RMSEA, $\chi 2 / \mathrm{df}, \mathrm{SRMR}, \mathrm{NFI}, \mathrm{TLI}$, and CFI) were looked at to gain a more comprehensive view of the model, in line with Schermelleh-Engel et al. (2003).

Finally, multiple group analyses between the different treatment and control groups were carried out within SPSS Amos 25. First, to compare values between groups, measurement invariance was assessed (Horn and McArdle, 1992). In line with Temme and Hildebrandt (2009), homogeneity of covariance matrices between the groups, configural invariance, and metric invariance were tested. In order to compare multiple groups, the factor loadings across those groups were held constant and the path coefficients obtained for each group were compared. To determine significant differences in the path coefficients between treatment groups, a pairwise comparison using a $\chi 2$ difference test was carried out.

\section{Results}

Results of the confirmatory factor analysis confirmed all constructs of the TPB, but led to the exclusion of the second item in the PBC scale ("How difficult would it be for you to reduce food waste at home?'). After the exclusion of the respective item, all scales had acceptable to high reliabilities (see Appendix, Table A4).

\subsection{Consumers' Food Waste Perception and Knowledge}

Attitude, Norms, PBC and Intention towards Food Waste Reduction. The constructs of attitude, norms, PBC and intention were analyzed first and results are reported in Table 1. The findings show that respondents generally have a favorable attitude towards reducing food waste. Personal norm is high amongst respondents, suggesting that most respondents have a bad conscience or feel guilty when throwing away food. Respondents' scores for subjective norm (e.g. food waste expectations and beliefs of acquaintances) are relatively low in all countries. When it comes to PBC, most respondents acknowledge that they possess a certain 
degree of control over their food waste behavior. The intention to reduce food waste is relatively high amongst respondents. Results for attitude, norms, $\mathrm{PBC}$ and intention in the three different countries are reported in the Appendix, Table A5.

\section{Table 1 around here}

Food Waste Knowledge. Respondent's general knowledge about food waste (e.g., food waste statistics) is rather poor with an average of around $34 \%$ correct answers (see Table 2). For instance, only a third of respondents know that households are the main contributor to food waste. Respondents' system knowledge regarding food waste is even lower, with an average of around $30 \%$ correct answers. In particular, respondents are not aware of the magnitude of $\mathrm{CO}_{2}$ emissions that are related to household food waste or the number of people that could be fed with all the food that is lost or wasted. Action-related knowledge related to food waste is greater with an average of around 51\% correct answers. The meaning of the 'best before' date, for instance, is understood by most respondents (around 80\% correct answers). However, respondents seem to be less familiar with the meaning of the 'use by' date (around 50\% correct answers). Results for knowledge in the three different countries are reported in the Appendix, Table A6.

\section{Table 2 around here}

\subsection{The Effect of Additional Information on Consumers' Intention, Attitude, Norms, and PBC}

Prior Knowledge Differences Prior knowledge differences were examined between control and treatment groups (see Appendix, Table A7). There are no significant knowledge differences except between $\mathrm{C} 2$ and the other groups. These differences can be explained by the survey design. $\mathrm{C} 2$ answered the quiz at the very end of the survey and some previous questions may have informed them about certain aspects such as the correct fridge temperature.

General Information Effect. To test for a general information effect, control groups $\mathrm{C} 1$ and $\mathrm{C} 2$ were combined into a single control group while treatment groups T1 and T2 were combined into a single treatment group. Results from a t-test show that intention to reduce food waste is significantly higher in the combined treatment group $\left(\mathrm{M}_{\mathrm{T}}=5.67, \mathrm{SD}_{\mathrm{T}}=1.26\right)$ as compared to the control group $\left(\mathrm{M}_{\mathrm{C}}=5.50, \mathrm{SD}_{\mathrm{C}}=1.37\right), \mathrm{t}=3.110, \mathrm{p}<.01, \mathrm{~d}=.13$. Mean scores for intention to reduce food waste are .17 (95\% CI $[.06, .28])$ higher for the treatment 
375

376

377

378

379

380

381

382

383

384

385

386

387

388

389

390

391

392

393

394

395

396

397

398

399

400

401

402

403

404

group. Therefore, respondents who received information have a significantly higher intention to reduce food waste.

Impact vs. Action-related Information Effect. For the remaining analyses, treatment and control groups were analyzed individually. Table 3 shows the means and standard deviations of the TPB constructs for all groups $(\mathrm{C} 1, \mathrm{C} 2, \mathrm{~T} 1$, and T2) and for the complete sample. F-Test statistics and corresponding p-values from the ANOVA are reported. Results show that the groups differ significantly regarding personal norm $\left(\mathrm{p}<.001, \eta^{2}=.009\right)$, attitude $\left(\mathrm{p}<.001, \eta^{2}\right.$ $=.009), \operatorname{PBC}\left(\mathrm{p}<.05, \eta^{2}=.004\right)$, and intention $\left(\mathrm{p}<.05, \eta^{2}=.005\right)$. There are no significant differences in subjective norm between treatment and control groups.

\section{Table 3 around here}

No significant difference was found for personal norm between T1 and either of the control groups (see Table 4). However, T2 shows significantly higher scores for personal norm than C2, but not C1. Similarly, T1 and T2 respondents' attitude scores were significantly higher than those of $\mathrm{C} 2$ respondents. There was no significant difference in attitude between T1, T2 and $\mathrm{C} 1$. For PBC, T2 respondents show significantly higher levels of PBC than $\mathrm{C} 2$. The differences between all other groups remain non-significant. Finally, results for intention to reduce food waste show that only $\mathrm{T} 2$ respondents demonstrate a significantly higher intention to reduce food waste compared to $\mathrm{C} 2$ respondents. There were no significant differences between any other groups.

\section{Table 4 around here}

Quiz Effect. To test for a possible quiz effect, the two control groups C1 and C2 were compared. Results show no significant difference in the intention to reduce food waste between the two control conditions. Therefore, a mere quiz effect on the change in intention can be rejected. However, $\mathrm{C} 1$ and $\mathrm{C} 2$ differ significantly in other constructs. $\mathrm{C} 1$ respondents report significantly higher scores for personal norm and attitude compared to $\mathrm{C} 2$ respondents.

\subsection{Food Waste, Knowledge and the Theory of Planned Behavior}

Goodness-of-Fit of the TPB Model. The $\chi^{2}$ value $(\chi 2=84.835$, $\mathrm{df}=34)$ shows an acceptable model fit. The RMSEA (.026), SRMR (.0155), NFI (.995), TLI (.995), and CFI (.997) suggest that the hypothesized model fits the data well. An overview of selected 
goodness-of-fit statistics for the TPB model is presented in the Appendix, Table A8, and compared to their respective requirements for good model fit.

\section{Figure 2 around here}

Figure 2 shows the standardized estimates of the path model. All paths theoretically postulated by the TPB prove to be significant. Also the extension (personal norm) influences intention significantly in a positive way. The influence of personal norm (.27), attitude (.23), and subjective norm (.20) on intention clearly exceeds that of PBC (.06), with personal norm being the strongest influence on intention. However, the differences in the standardized estimates between personal norm, subjective norm, and attitude are rather small, suggesting that all three constructs influence intention to reduce food waste in a similarly strong way. All constructs are significantly positively correlated. The correlations are medium, with attitude and personal norm (.57) as well as attitude and PBC (.51) showing the highest correlations. The proportion of variance of intention that can be explained by the four constructs (personal norm, subjective norm, attitude, and PBC) is $35 \%$.

Mediation Effect. To test whether there are mediation effects of attitude, norms, and PBC, the model was also tested individually for the four different information treatment groups $\mathrm{C} 1$, C2, T1, and T2. Results from the corresponding validity checks are reported in the Appendix, Tables A9 and A10. Pairwise comparisons of the groups' path coefficients using $\chi 2$ difference tests show that the differences in the path coefficients are not significant. The coefficients are reported in the Appendix, Table A11, and the resulting p-values are reported in the Appendix, Table A12. Consequently, the four groups do not differ significantly in how subjective norm, personal norm, attitude, and PBC influence intention to reduce food waste.

\section{Discussion}

Attitude, Norms, PBC and Intention towards Food Waste Reduction. Generally, respondents score relatively high on attitude, personal norm, PBC and intention to reduce food waste. Interestingly, compared to personal norm, scores for subjective norm are low, suggesting that people have a self-expectation that goes beyond what they think about what others do and expect of them. Respondents in the present study feel guilty when wasting food but they do not believe that their peers try to reduce food waste or want them to do so. This finding contradicts previous research that reports high scores for subjective norm (e.g., Russel et al., 2017) and/or similar levels for subjective and personal/moral norm (e.g., Graham-Rowe 
et al., 2015; Visschers et al., 2016). A possible reason for the low subjective norm scores (especially in comparison with personal norm) in the present study could be that food waste mostly happens in the home and is consequently a private behavior that cannot be observed by others. Respondents might feel guilty about food waste but since their peers do not see this behavior, they do not feel obliged to reduce their food waste. Another possible explanation could be that respondents in this sample feel they already waste very little food compared to their peers which may lead to a low score for subjective norm. However, they might still feel guilty when throwing out food (leading to a high score in personal norm) even though (they think) they rarely do so.

Food Waste Knowledge. The findings show that respondents' general food waste knowledge and their food waste system knowledge are rather poor. Concerning the food waste actionrelated knowledge dimension such as the storage of certain food items, consumers' knowledge is slightly better. The poor system knowledge finding is in line with previous studies confirming that consumers lack awareness, especially of environmental consequences of food waste (Brook Lyndhurst et al., 2007; Watson and Meah, 2012). It is perhaps surprising that only one third of respondents is aware that households are the major source of food waste. It seems that consumers underestimate their own responsibility in relation to the food waste problem. Rather, producers or retailers are blamed. The ignorance of responsibility may in fact lead to people behaving in less environmentally friendly ways (Kollmuss and Agyeman, 2002) and therefore serves as a possible explanation for the high level of household food waste in the respective countries (Bräutigam et al., 2014).

Information Effect on Intention. This study's results confirm an information effect on intention to reduce food waste. Taken together, the treatment groups have a significantly higher intention to reduce food waste than the control groups. This is in line with previous findings (e.g., Liz Martins et al., 2016). Looking at the effect of the two different information treatments individually, the results show that only the group receiving action-related information (T2) shows a significantly higher intention to reduce food waste compared to the group who did not participate in the quiz mid-survey (C2). However, there are no significant differences in intention to reduce food waste between the two treatment groups or between either treatment condition and the control group who received the quiz without feedback $(\mathrm{C} 1)$. Even though $\mathrm{C} 1$ and $\mathrm{C} 2$ do not differ in their intention to reduce food waste, $\mathrm{C} 1$ reports significantly higher scores for personal norm and attitude. Therefore, while a mere quiz effect in the change of intention to reduce food waste can be rejected, a quiz effect on the constructs 
personal norm and attitude cannot be ruled out. The difference between $\mathrm{C} 1$ and $\mathrm{C} 2$ as well as the non-existing difference between $\mathrm{C} 1$ and the treatment groups $\mathrm{T} 1$ and $\mathrm{T} 2$ may point to a salience rather than an information effect. The information provided may not have increased knowledge, however the mere process of taking part in the quiz could have made already existing knowledge more salient and thus led to increased scores for attitude and norms, also for $\mathrm{C} 1$ respondents.

Information Effect on Attitude, Norms, and PBC. The higher intention to reduce food waste for the action-related information group (T2) can be traced back to significantly higher scores in personal norm, attitude and PBC compared to C2. The higher scores in PBC and attitude were expected, as the practical tips provided by the action-related information were designed to make respondents feel more capable of reducing food waste in their home, and therefore evaluate it more favorably as well. Interestingly, the action-related information seems to have increased respondents' scores for personal norm towards food waste reduction, i.e., their feeling of guilt when wasting food. One explanation could be that providing actionrelated information demonstrated that reducing food waste is not complicated but achievable by most. If realizing a desired behavior is not that complicated, not engaging with that behavior may lead to increased feelings of guilt. Even though no significant intention change is observed in the system information group, they score significantly higher than $\mathrm{C} 2$ on attitude. This indicates that, in line with the authors' expectations, a confrontation with the negative impacts of food waste increases respondents' attitude towards reducing it. Still, the more favorable attitude does not translate into higher intention to reduce food waste. Therefore, the findings partly contradict the authors' previous assumptions. A potential explanation might be that the information provided was limited and possibly too intangible which may have made it not relatable enough to result in an increase in behavioral intention to reduce food waste. Water scarcity, for example, is currently not a big concern in the investigated countries and the amount of $\mathrm{CO}_{2}$ emissions emitted by food waste may be hard to grasp. Even though unexpected, the results confirm findings from Ajzen et al. (2011) who investigated the role of information accuracy in predicting energy saving and drinking behavior and intentions.

The TPB Model. Results regarding the extended TPB model suggest that all paths theoretically postulated by the TPB as well as the newly included construct of personal norm significantly influence intention to reduce food waste. However, the influence of personal norm, attitude, and subjective norm on intention clearly exceeds that of PBC. The small effect 
of PBC is in line with previous findings from Stancu et al. (2016) who did not find significant effects of PBC on intention at all. However, the present study's finding contradicts other research that has found PBC to be one of the important predictors of intention (Graham-Rowe et al., 2015; Russell et al., 2017; Visschers et al., 2016). Given the significant influence of personal norm which has also been observed in previous studies (Lorenz et al., 2017a; Visschers et al., 2016), the incorporation of this construct into the model of the TPB when investigating food waste or related behaviors is supported. When testing the path model within each treatment/control group, results show that the differences in coefficients are not significant across groups for either construct. Therefore, the results do not confirm significant differences of how system and action-related information influence intention within the TPB model.

\subsection{Implications}

This study shows that the level of knowledge concerning food waste and how to avoid it among consumers in Belgium, Germany, and the UK is rather low and therefore needs to be improved. Based on the results obtained in this study, it is recommended that policy makers and NGOs launch more consumer education campaigns using action-related information; educating consumers about how to store food products to keep them fresh the longest, at what temperature to set their fridge, the importance of planning meals and writing a shopping list, to name just a few.

The importance of personal norms in predicting behavioral intention indicates that campaigns should further focus on communicating the moral obligation to reduce food waste. In that context, it is important to note that previous findings show that simply blaming the consumer and eliciting feelings of guilt may not be effective in reducing waste (Birau and Faure, 2018). Therefore, further research on how campaigns can increase consumers' personal norm without unwanted side effects is required. For instance, effort could be directed towards alerting consumers about the magnitude of household food waste since the ascription of responsibility is considered a prerequisite for the emergence of negative emotions, and this may in turn strengthen personal norms.

Moreover, the way the information was presented to respondents might have played an important role. Previous research on environmental behavior (e.g., Cialdini, 2003) suggests that information campaigns with different message framing can differ significantly in their 
effectiveness. This line of research should be extended to the food waste field. Since the increase in intention caused by the action-related information was rather small, additional ways to influence consumers' intention and eventually their behavior regarding food waste should be explored. In the end, the model accounted for only $35 \%$ of the variance in behavioral intention, suggesting that other constructs influence food waste intention and behavior. Therefore, future research should include additional constructs in their models explaining household food waste behavior. Next to investigating how to prevent food waste, it is also important to further investigate methods of food waste recovery, either in the household (e.g. motivate consumers to participate in food sharing initiatives) (e.g., Lazell, 2016) or in industry (e.g. via the method of biochar farming) (Maroušek et al., 2019).

\subsection{Limitations}

There were methodological limitations to this study which could partially affect the generalizability of the results. First, the findings depend on self-reported consumer data which is prone to bias, particularly when it comes to emotionally charged topics, causing responses to be biased towards appropriate social norms. Food waste can be such an emotional topic since it is often associated with feelings of shame and guilt (Quested et al., 2013). This is confirmed by respondents' feedback to the questionnaire which included a number of comments and justifications of people claiming never to waste food. Furthermore, this study was not able to measure actual food waste behavior. Instead, behavioral intention was the final dependent variable in this study. Measuring real life food waste behavior is difficult. Although there are several methods such as food waste diaries and self-report questionnaires, those are expensive and/or usually biased (Jörissen et al., 2015). Even though low response rates are common in online surveys, it has to be addressed that the response rate of the present survey was at $22 \%$. A possible reason might be the length of the questionnaire which took respondents on average about 28 minutes to complete. However, representativeness of the sample to the respective countries' population was still ensured using quotas, thus reducing the risk of non-response bias.

It should also be stated that the effectiveness of educating people - especially in the long-term - is debatable. Some researchers argue that education campaigns alone may not be enough to change the underlying norms and habits that lead to food waste behavior (Gjerris and Gaiani, 2013; Hebrok and Boks, 2017; Quested et al., 2013). Liz Martins et al. (2016), for instance, who implemented different education campaigns in three schools in Portugal, show that 
education measures designed for children reduced plate waste at first. However, this effect decreased after a period of three months. A campaign targeted at teachers was more effective. Even though the present study confirms the effect of information, it has to be pointed out that effect sizes were rather small. Moreover, while this study focused on objective knowledge, previous research has shown that subjective knowledge might be even more important in environmentally sustainable consumption choices (Peschel et al., 2016).

Moreover, this study only investigated consumers from Belgium, Germany and the UK. The sample was representative for the respective countries which means that the results can be generalized onto the overall population of those countries. Since there were little differences between the three countries, it can be assumed that the results of this study can also be generalized onto similar countries, i.e., other industrialized ones. On a global level, though, results may vary. Countries differ in the stage of the supply chain at which most food waste is created. In developing countries, the majority of food waste does not happen at the consumption stage but in earlier supply chain stages. As a consequence, rather than investigating whether the results of this study could be adapted to those countries, further research needs to address how to avoid food waste in earlier supply chain stages. Lastly, a sole focus on individual food waste prevention is not sufficient. In order to substantially decrease food waste, a holistic approach including consumers, policy makers, and stakeholders along the supply chain is indispensable (Schanes et al., 2018).

\section{Conclusion}

The findings of this study show that action-related information significantly increases consumers' behavioral intention to reduce food waste while system information has no direct effect on intention although it results in more favorable attitudes towards food waste reduction. To the best of the authors' knowledge, this is the first study to compare how those different types of information influence consumers' intention towards reducing food waste.

These findings are important for both practitioners and researchers and they are especially relevant in sight of the Sustainable Development Goal 12.3 to halve global per capita food waste as proposed by the United Nations. The study's findings stress the importance of action-related information in changing consumer behavior and they represent an important foundation for the development of future campaigns and educational material aimed at influencing cognitive drivers of food waste generation to change consumer behavior. Since 
600 consumers (and especially those in Western countries) are a major contributor to the food 601 waste problem, changing their behavior is an important step towards reducing global food 602 waste and thus fighting climate change.

603 Lastly, the results contribute to the ongoing scientific debate about factors influencing food 604 waste intention and behavior. The central role of attitudes, norms and PBC has been 605 confirmed and insights into causal mechanisms involved in the intention formation process 606 are provided. 
608

609

610

611

612

613

614

615

616

617

618

619

620

621

622

623

624

625

626

627

628

629

630

631

632

633

634

635

636

637

638

639

640

641

642

643

644

645

Ajzen, I., 1991. The theory of planned behavior. Organizational Behavior and Human Decision Processes 50, 179-211.

Ajzen, I., Joyce, N., Sheikh, S., Cote, N.G., 2011. Knowledge and the Prediction of Behavior: The Role of Information Accuracy in the Theory of Planned Behavior. Basic and Applied Social Psychology 33, 101-117.

Birau, M.M., Faure, C., 2018. It is easy to do the right thing: Avoiding the backfiring effects of advertisements that blame consumers for waste. Journal of Business Research 87, 102 117.

Bräutigam, K.-R., Jörissen, J., Priefer, C., 2014. The extent of food waste generation across EU-27: different calculation methods and the reliability of their results. Waste Management \& Research 32, 683-694.

Brook Lyndhurst Ltd, Cox, J., Downing, P., 2007. Food behaviour consumer research: quantitative phase. WRAP, UK. http://www.wrap.org.uk/sites/files/wrap/Food\%20behaviour\%20consumer\%20research\%2 Oquantitative\%20jun\%202007.pdf. Accessed October 10, 2019.

Brucks, M., 1985. The Effects of Product Class Knowledge on Information Search Behavior. Journal of Consumer Research 12, 1-16.

Cialdini, R.B., 2003. Crafting Normative Messages to Protect the Environment. Current Directions in Psychological Science 12, 105-109.

Díaz-Ruiz, R., Costa-Font, M., Gil, J.M., 2015. A social perspective on food waste: to what extent consumers are aware of their own food waste, in: Escajedo San-Epifanio, L., De Renobales Scheifler, M. (Eds.), Envisioning a future without food waste and food poverty. Societal challenges. Wageningen Academic Publishers, Wageningen, 157-164.

Díaz-Ruiz, R., Costa-Font, M., Gil, J.M., 2018. Moving ahead from food-related behaviours: an alternative approach to understand household food waste generation. Journal of Cleaner Production 172, 1140-1151.

Ernst, A.M., 1994. Soziales Wissen als Grundlage des Handelns in Konfliktsituationen. P. Lang, Frankfurt am Main, New York.

Exodus Market Research, 2007. We Don't Waste Food! A Householder Survey. Retail Programme - Food Waste: Final Report. WRAP, UK. http://www.wrap.org.uk/sites/files/wrap/We_don_t_waste_food_A_household_survey_mar_07.db6802f9.6397.pdf. Accessed October 10, 2019.

FAO, 2011. Global food losses and food waste. Extent, causes and prevention, Study conducted for the International Congress SAVE FOOD! at Interpack2011, Düsseldorf, Germany. http://www.fao.org/docrep/014/mb060e/mb060e.pdf. Accessed October 22, 2019.

FAO, 2013. Food wastage footprint: impacts on natural resources. http://www.fao.org/docrep/018/i3347e/i3347e.pdf. Accessed January 232020. 
Farr-Wharton, G., Foth, M., Choi, J.H.-J., 2014. Identifying factors that promote consumer behaviours causing expired domestic food waste. Journal of Consumer Behavior 13, 393402.

Frick, J., Kaiser, F.G., Wilson, M., 2004. Environmental knowledge and conservation behavior: exploring prevalence and structure in a representative sample. Personality and Individual Differences 37, 1597-1613.

Gjerris, M., Gaiani, S., 2013. Household food waste in Nordic countries: Estimations and ethical implications. Etikk Praksis - Nordic Journal of Applied Ethics 7, 6-23.

Graham-Rowe, E., Jessop, D.C., Sparks, P., 2014. Identifying motivations and barriers to minimising household food waste. Resources, Conservation and Recycling 84, 15-23.

Graham-Rowe, E., Jessop, D.C., Sparks, P., 2015. Predicting household food waste reduction using an extended theory of planned behaviour. Resources, Conservation and Recycling 101, 194-202.

Hamari, J., Sjöklint, M., Ukkonen, A., 2016. The sharing economy: Why people participate in collaborative consumption. Journal of the Association for Information Science and Technology 67, 2047-2059.

Hebrok, M., Boks, C., 2017. Household food waste: Drivers and potential intervention points for design - An extensive review. Journal of Cleaner Production 151, 380-392.

Horn, J.L., McArdle, J.J., 1992. A practical and theoretical guide to measurement invariance in aging research. Experimental Aging Research 18, 117-144.

Jörissen, J., Priefer, C., Bräutigam, K.-R., 2015. Food Waste Generation at Household Level: Results of a Survey among Employees of Two European Research Centers in Italy and Germany. Sustainability 7, 2695-2715.

Kaiser, F.G., Fuhrer, U., 2003. Ecological Behavior's Dependency on Different Forms of Knowledge. Applied Psychology 52, 598-613.

Kim, J.-O., Ferree, G.D., 1981. Standardization in Causal Analysis. Sociological Methods \& Research 10, 187-210.

Kollmuss, A., Agyeman, J., 2002. Mind the Gap: Why do people act environmentally and what are the barriers to pro-environmental behavior? Environmental Education Research 8, 239-260.

Lazell, J., 2016. Consumer food waste behaviour in universities: Sharing as a means of prevention. Journal of Consumer Behavior 15, 430-439.

Liz Martins, M., Rodrigues, S.S., Cunha, L.M., Rocha, A., 2016. Strategies to reduce plate waste in primary schools - experimental evaluation. Public Health Nutrition 19, 15171525.

Lorenz, B.A., Hartmann, M., Hirsch, S., Kanz, O., Langen, N., 2017a. Determinants of Plate Leftovers in One German Catering Company. Sustainability 9, 807. 
Lorenz, B.A., Hartmann, M., Langen, N., 2017b. What makes people leave their food? The interaction of personal and situational factors leading to plate leftovers in canteens. Appetite 116, 45-56.

Maroušek, J., Kondo, Y., Ueno, M., Kawamitsu, Y., 2013. Commercial-scale utilization of greenhouse residues. Biotechnology and Applied Biochemistry 60, 253-258.

Maroušek, J., Strunecký, O., Stehel, V., 2019. Biochar farming: defining economically perspective applications. Clean Technologies and Environmental Policy 21, 1389-1395.

Monier, V., Mudgal, S., Escalon, V., O’Connor, C., Gibon, T., Anderson, G., Montoux, H., Reisinger, H., Dolley, P., Ogivie, S., \& Morton, G., 2010. Preparatory study on food waste across EU 27. Technical Report - 2010 - 054, European Commission. http://ec.europa.eu/environment/eussd/pdf/bio_foodwaste_report.pdf. Accessed October $22,2019$.

Neff, R.A., Spiker, M.L., Truant, P.L., 2015. Wasted Food: U.S. Consumers' Reported Awareness, Attitudes, and Behaviors. PLOS ONE 10, e0127881.

Pakpour, A.H., Zeidi, I.M., Emamjomeh, M.M., Asefzadeh, S., Pearson, H., 2014. Household waste behaviours among a community sample in Iran: An application of the theory of planned behaviour. Waste Management 34, 980-986.

Parfitt, J., Barthel, M., Macnaughton, S., 2010. Food waste within food supply chains: quantification and potential for change to 2050. Philosophical transactions of the Royal Society B, Biological Sciences 365, 3065-3081.

Peschel, A.O., Grebitus, C., Steiner, B., Veeman, M., 2016. How does consumer knowledge affect environmentally sustainable choices? Evidence from a cross-country latent class analysis of food labels. Appetite 106, 78-91.

Quested, T.E., Marsh, E., Stunell, D., Parry, A.D., 2013. Spaghetti soup: The complex world of food waste behaviours. Resources, Conservation and Recycling 79, 43-51.

Reynolds, C., Goucher, L., Quested, T., Bromley, S., Gillick, S., Wells, V.K., Evans, D., Koh, L., Carlsson Kanyama, A., Katzeff, C., Svenfelt, Å., Jackson, P., 2019. Review: Consumption-stage food waste reduction interventions - What works and how to design better interventions. Food Policy 83, 7-27.

Richter, B., 2017. Knowledge and perception of food waste among German consumers. Journal of Cleaner Production 166, 641-648.

Russell, S.V., Young, C.W., Unsworth, K.L., Robinson, C., 2017. Bringing habits and emotions into food waste behaviour. Resources, Conservation and Recycling 125, 107114.

Schahn, J., Holzer, E., 1990. Studies of Individual Environmental Concern: The role of knowledge, gender, and background variables. Environment and Behavior 22, 767-786.

Schanes, K., Dobernig, K., Gözet, B., 2018. Food waste matters - A systematic review of household food waste practices and their policy implications. Journal of Cleaner Production 182, 978-991. 
Schermelleh-Engel, K., Moosbrugger, H., Müller, H.H., 2003. Evaluating the fit of structural equation models: tests of significance and descriptive goodness-of-fit measures. Methods of Psychological Research Online 8, 23-74.

Schmidt, K., 2016. Explaining and promoting household food waste-prevention by an environmental psychological based intervention study. Resources, Conservation and Recycling 111, 53-66.

Schwartz, S.H., 1973. Normative explanations of helping behavior: A critique, proposal, and empirical test. Journal of Experimental Social Psychology 9, 349-364.

Stancu, V., Haugaard, P., Lähteenmäki, L., 2016. Determinants of consumer food waste behaviour: Two routes to food waste. Appetite 96, 7-17.

Stefan, V., van Herpen, E., Tudoran, A.A., Lähteenmäki, L., 2013. Avoiding food waste by Romanian consumers: The importance of planning and shopping routines. Food Quality and Preference 28, 375-381.

Stenmarck, A., Jensen, C., Quested, T., Moates, G., 2016. Estimates of European food waste levels, IVL Swedish Environmental Research Institute, Stockholm. https://www.eufusions.org/phocadownload/Publications/Estimates\%20of\%20European\%20food\%20wast e\%20levels.pdf. Accessed December 12, 2019.

Temme, D., Hildebrandt, L., 2009. Gruppenvergleiche bei hypothetischen Konstrukten - Die Prüfung der Übereinstimmung von Messmodellen mit der Strukturgleichungsmethodik. Schmalenbachs Zeitschrift für betriebswirtschaftliche Forschung 61, 138-185.

Thøgersen, J., 2006. Norms for environmentally responsible behaviour: An extended taxonomy. Journal of Environmental Psychology 26, 247-261.

van der Werf, P., Seabrook, J.A., Gilliland, J.A., 2019. Food for naught: Using the theory of planned behaviour to better understand household food wasting behaviour. The Canadian Geographer / Le Géographe canadien 63, 478-493.

Visschers, V.H.M., Wickli, N., Siegrist, M., 2016. Sorting out food waste behaviour: A survey on the motivators and barriers of self-reported amounts of food waste in households. Journal of Environmental Psychology 45, 66-78.

Watson, M., Meah, A., 2012. Food, Waste and Safety: Negotiating Conflicting Social Anxieties into the Practices of Domestic Provisioning. The Sociological Review 60, 102120.

Williams, H., Wikström, F., Otterbring, T., Löfgren, M., Gustafsson, A., 2012. Reasons for household food waste with special attention to packaging. Journal of Cleaner Production $24,141-148$. 


\section{Figures}

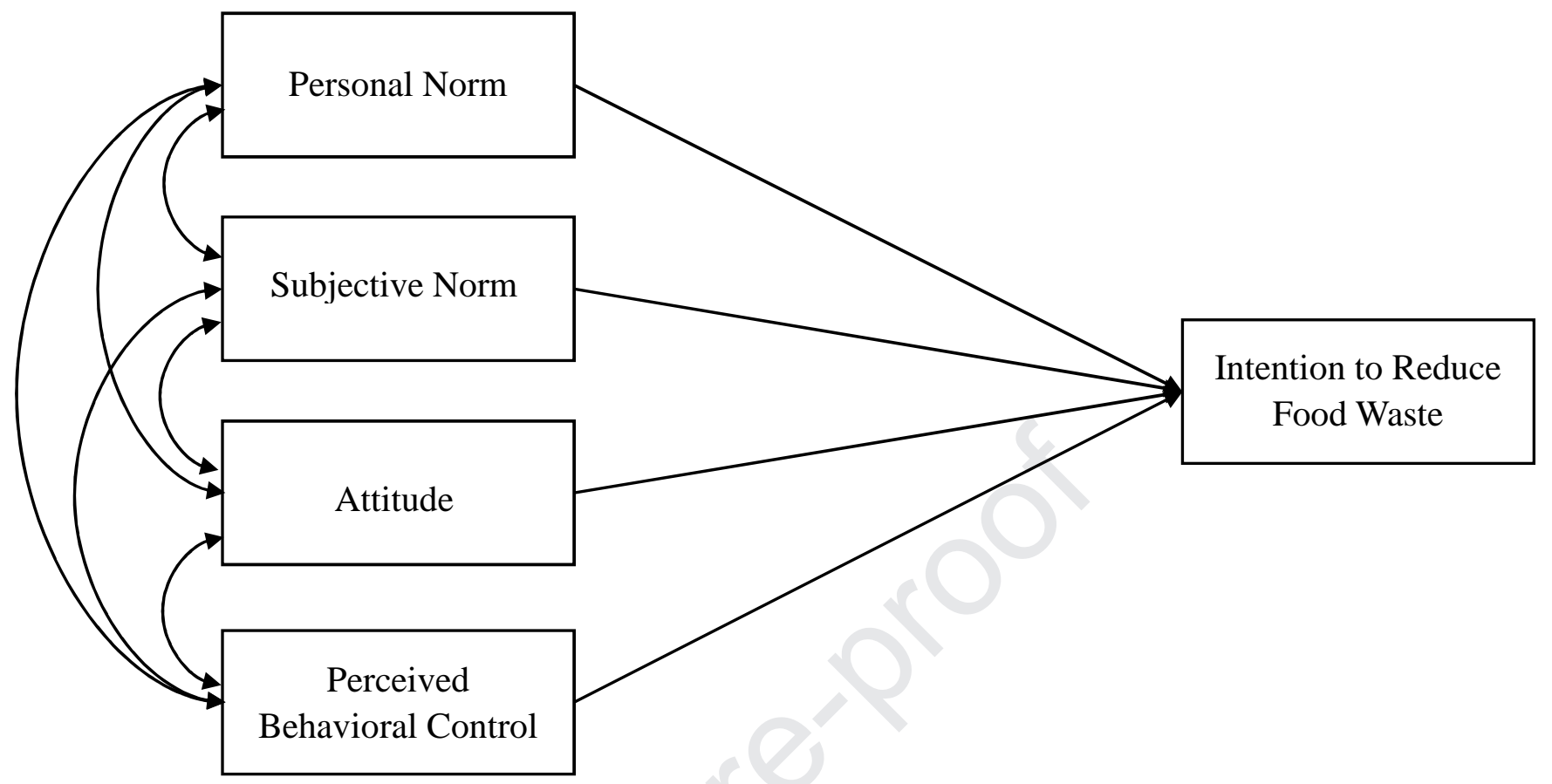

Figure 1: Hypothesized Path Model

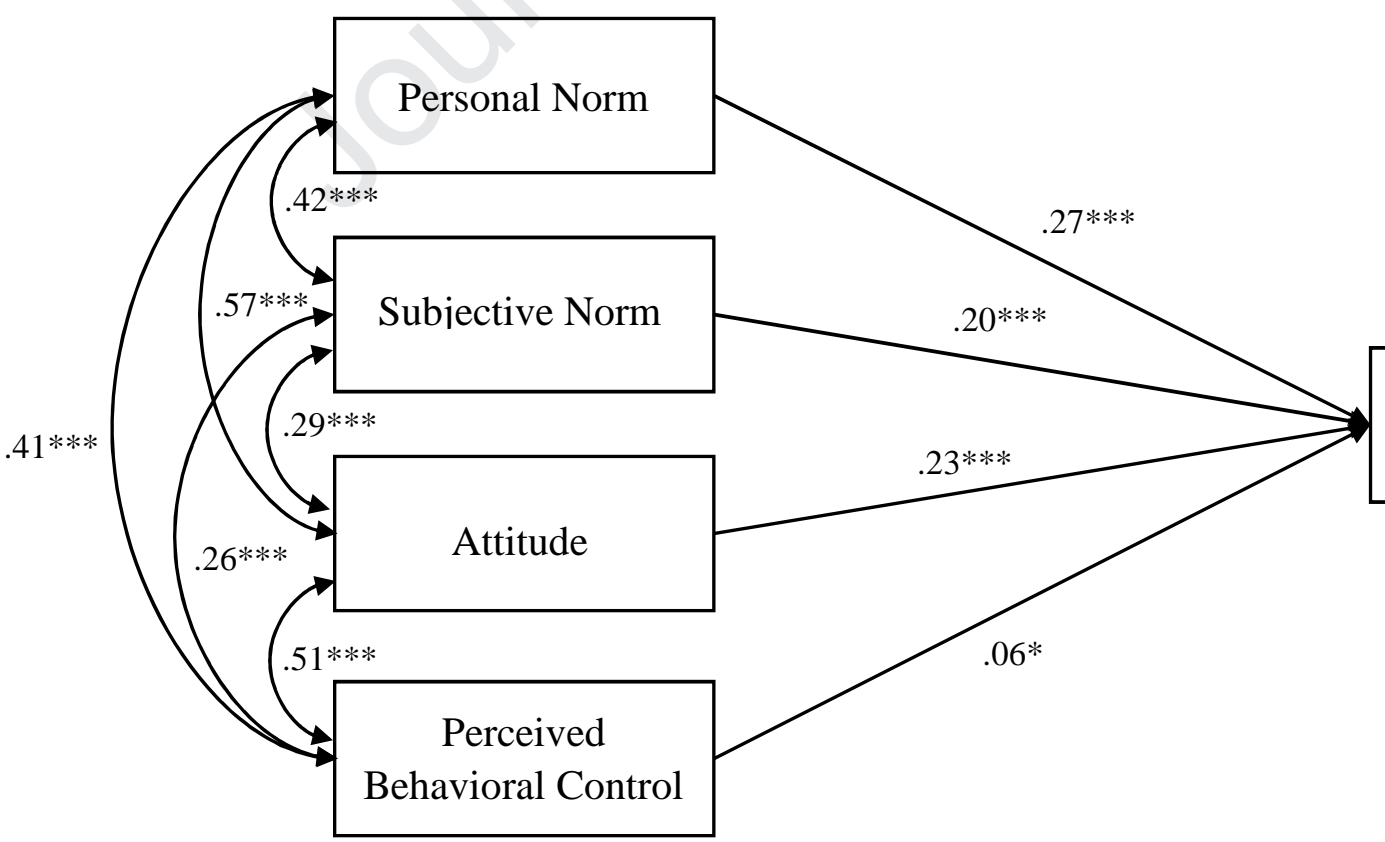

Intention to Reduce

Food Waste

Figure 2: Standardized estimates for the complete sample $\mathrm{N}=2248, * * * \mathrm{p}<.001, * * \mathrm{p}<.01, * \mathrm{p}<.05$ 


\section{Tables}

Table 1: TPB Constructs - Means and Standard Deviations (SD)

\begin{tabular}{lrr}
\hline Construct & Mean & SD \\
\hline Personal Norm $^{\mathrm{A}}$ & 3.94 & .82 \\
Subjective Norm $^{\mathrm{A}}$ & 2.42 & .52 \\
Attitude $^{\mathrm{B}}$ & 5.98 & .96 \\
PBC $^{\mathrm{A}}$ & 3.72 & .65 \\
Intention $^{\mathrm{B}}$ & 5.59 & 1.32
\end{tabular}

${ }^{\mathrm{A}}$ Constructs measured on a 5-point Likert scale

${ }^{\mathrm{B}}$ Constructs measured on a 7-point Likert scale

Table 2: Food Waste Knowledge - Percentage of average correct responses per knowledge dimension

\begin{tabular}{lr}
\hline Questions & $\begin{array}{r}\text { Percentage of respondents } \\
\text { that answered correctly }\end{array}$ \\
\hline General Knowledge $(\mathrm{N}=2,248)$ & 33.64 \\
\hline System Knowledge $(\mathrm{N}=1,685)$ & 29.64 \\
\hline Action-related Knowledge $(\mathrm{N}=1,124)$ & 50.77 \\
\hline
\end{tabular}


Table 3: Means and standard deviations for treatment and control groups, F-test statistic and corresponding P-value.

\begin{tabular}{|c|c|c|c|c|c|c|}
\hline & & Mean & $\begin{array}{l}\text { Standard } \\
\text { Deviation }\end{array}$ & F-Test & P-Value & $\mathbf{N}$ \\
\hline \multirow{5}{*}{$\begin{array}{l}\text { Personal } \\
\text { Norm }\end{array}$} & Control 1 & 3.99 & .82 & & & 561 \\
\hline & Control 2 & 3.81 & .88 & & & 561 \\
\hline & System Info (T1) & 3.94 & .77 & & & 563 \\
\hline & Action Info (T2) & 4.01 & .78 & & & 563 \\
\hline & Total & 3.94 & .82 & $5.962^{\mathrm{a}}$ & .000 & 2248 \\
\hline \multirow{5}{*}{$\begin{array}{l}\text { Subjective } \\
\text { Norm }\end{array}$} & Control 1 & 2.44 & .54 & & & 561 \\
\hline & Control 2 & 2.40 & .53 & & & 561 \\
\hline & System Info (T1) & 2.40 & .53 & & & 563 \\
\hline & Action Info (T2) & 2.43 & .49 & & & 563 \\
\hline & Total & 2.42 & .52 & .777 & .507 & 2248 \\
\hline \multirow[t]{5}{*}{ Attitude } & Control 1 & 6.01 & .92 & & & 561 \\
\hline & Control 2 & 5.83 & 1.05 & & & 561 \\
\hline & System Info (T1) & 5.99 & .99 & & & 563 \\
\hline & Action Info (T2) & 6.08 & .87 & & & 563 \\
\hline & Total & 5.98 & .96 & $6.378^{\mathrm{a}}$ & .000 & 2248 \\
\hline \multirow{5}{*}{$\begin{array}{l}\text { Perceived } \\
\text { Behavioral } \\
\text { Control }\end{array}$} & Control 1 & 3.70 & .67 & & & 561 \\
\hline & Control 2 & 3.69 & .65 & & & 561 \\
\hline & System Info (T1) & 3.72 & .66 & & & 563 \\
\hline & Action Info (T2) & 3.79 & .60 & & & 563 \\
\hline & Total & 3.72 & .65 & 3.085 & .026 & 2248 \\
\hline \multirow[t]{5}{*}{ Intention } & Control 1 & 5.52 & 1.36 & & & 561 \\
\hline & Control 2 & 5.48 & 1.38 & & & 561 \\
\hline & System Info (T1) & 5.63 & 1.24 & & & 563 \\
\hline & Action Info (T2) & 5.71 & 1.28 & & & 563 \\
\hline & Total & 5.59 & 1.32 & $3.617^{\mathrm{a}}$ & .013 & 2248 \\
\hline
\end{tabular}

${ }^{a}$ Welch's F, used for data that violated the assumption of homogeneity of variance. 
Table 4: Mean score separation (MS) with corresponding confidence intervals (CI) and p-values (P) for all treatment and control groups.

\begin{tabular}{|c|c|c|c|c|c|c|c|c|c|c|c|c|c|}
\hline & & \multicolumn{3}{|c|}{ Personal Norm $^{a}$} & \multicolumn{3}{|c|}{ Attitude $^{a}$} & \multicolumn{3}{|c|}{$\begin{array}{c}\text { Perceived Behavioral } \\
\text { Control }^{\mathbf{b}}\end{array}$} & \multicolumn{3}{|c|}{ Intention $^{\mathrm{a}}$} \\
\hline & & MS & $95 \%$ CI & $\mathrm{P}$ & MS & $95 \% \mathrm{CI}$ & $\mathrm{P}$ & MS & $95 \% \mathrm{CI}$ & $\mathrm{P}$ & MS & $95 \% \mathrm{CI}$ & $\mathrm{P}$ \\
\hline \multirow{3}{*}{$\begin{array}{l}\text { System } \\
\text { Info (T1) }\end{array}$} & Action Info & -.069 & $-.189 ; .050$ & .442 & -.093 & $-.236 ; .050$ & .335 & -.077 & $-.176 ; .022$ & .188 & -.081 & $-.275 ; .112$ & .700 \\
\hline & Control 1 & -.049 & $-.172 ; .074$ & .732 & -.022 & $-.169 ; .124$ & .980 & .014 & $-.086 ; .113$ & .985 & .113 & $-.086 ; .313$ & .460 \\
\hline & Control 2 & .126 & $-.001 ; .253$ & .053 & .157 & $.000 ; .314$ & .049 & .032 & $-.067 ; .131$ & .843 & .150 & $-.051 ; .351$ & .218 \\
\hline \multirow{2}{*}{$\begin{array}{l}\text { Action } \\
\text { Info (T2) }\end{array}$} & Control 1 & .020 & $-.103 ; .143$ & .975 & .071 & $-.067 ; .209$ & .547 & .091 & $-.009 ; .190$ & .087 & .195 & $-.008 ; .398$ & .065 \\
\hline & Control 2 & .195 & $.068 ; .323$ & .001 & .250 & $.101 ; .399$ & .000 & .109 & $.010 ; .208$ & .025 & .232 & $.027 ; .436$ & .019 \\
\hline Control 1 & Control 2 & .175 & $.044 ; .306$ & .003 & .179 & $.027 ; .331$ & .013 & .018 & $-.081 ; .118$ & .965 & .037 & $-.173 ; .247$ & 970 \\
\hline
\end{tabular}




\section{Online Appendix}

\section{Figures Online Appendix}

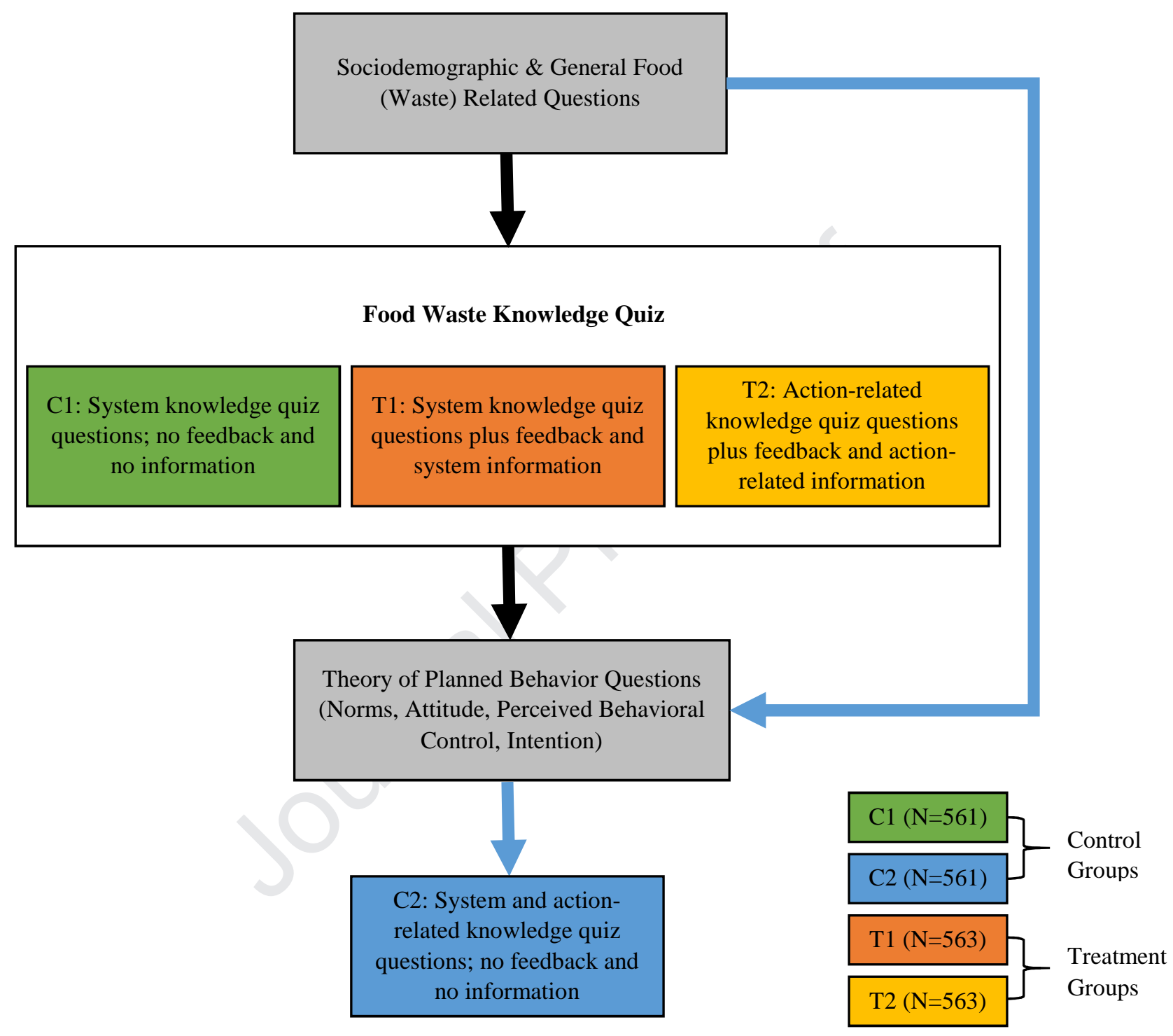

Figure A1: Flowchart Experimental Design 
Household food waste in Europe contributes 3.3 billion tons of greenhouse gas emissions. This corresponds to the annual $\mathrm{CO} 2$ emissions of approximately $\mathbf{4 0}$ million cars. If food waste was a country, it would be the third largest producer of $\mathrm{CO} 2$, tailing the USA and China.

The emission of $\mathrm{CO} 2$ results from the processes before (production, processing, retail, transport, ...) and after (collecting, treatment, ...) the food gets discarded.
$10 \%$ of all human-caused greenhouse gases contributing to climate change are linked to food waste.

Cutting down on your food waste will decrease your carbon footprint.

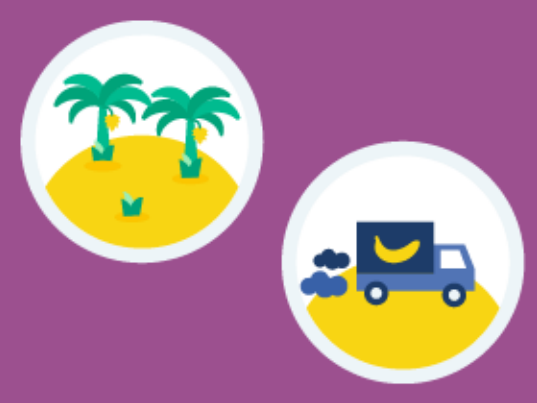

Figure A2: Example of System Information Treatment

'Best before' has nothing to do with food safety. Rather, it is a manufacturer's suggestion for peak quality and indicates the time until a food retains its specific properties (e.g. taste, colour and consistency) under appropriate storage conditions.

Food is still safe to consume after the indicated 'best before' date (if stored correctly). The food may only have lost its flavour or texture.
Recommendation: Food past its 'best before' date is oftentimes still edible. Therefore, check if the packaging is intact and if the food looks, smells and tastes good before throwing away food past its 'best before' date.

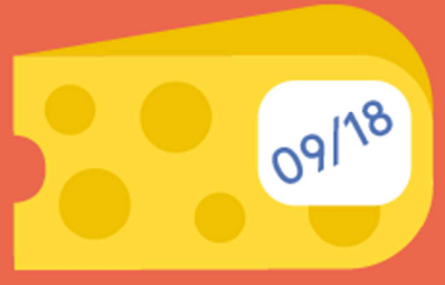

Figure A3: Example of Action-related Information Treatment 
What do we consider as food waste? Food waste only refers to food discarded, regardless of being spoilt or not, by wholesalers, retailers, the food service sector and households. At household level, food given to animals or food that is composted is considered as food waste.

Food waste does not refer to food discarded during production or processing.

It is important to note, though, that a large share of household food waste is actually avoidable.

We distinguish between unavoidable and avoidable food waste.

Unavoidable food waste refers to discarded parts of food that would have been inedible under normal circumstances anyway (e.g. bones, banana peels, eggshells, pineapple skins).

Avoidable food waste refers to discarded food that was still fit for human consumption at the time of disposal or would have been edible if used in time (e.g. leftovers from a meal, imperfect looking / misshapen fruits and vegetables, food that has gone (partly) mouldy or past its best before / use by date).
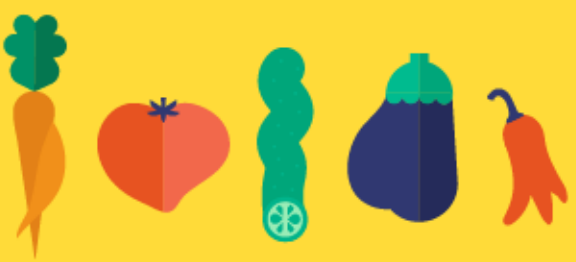

Figure A4: Food Waste Definition 
Tables Online Appendix

Table A1: Socio-Demographic Characteristics of the Sample

\begin{tabular}{|c|c|c|c|c|c|c|c|c|}
\hline \multicolumn{9}{|c|}{ Frequency (\%) } \\
\hline Variable & Total & $\begin{array}{l}\text { Bel- } \\
\text { gium }\end{array}$ & $\begin{array}{l}\text { Ger- } \\
\text { many }\end{array}$ & UK & $\mathrm{C} 1$ & $\mathrm{C} 2$ & $\mathrm{~T} 1$ & $\mathrm{~T} 2$ \\
\hline Gender (Male) & 49.0 & 48.9 & 49.1 & 49.1 & 49.0 & 49.2 & 49.0 & 48.8 \\
\hline \multicolumn{9}{|l|}{ Age } \\
\hline $18-35$ & 27.7 & 27.9 & 25.1 & 30.0 & 27.6 & 27.6 & 27.9 & 27.5 \\
\hline $36-45$ & 15.7 & 17.1 & 14.0 & 16.0 & 15.9 & 15.7 & 15.6 & 15.6 \\
\hline $46-55$ & 18.0 & 17.0 & 18.9 & 18.0 & 17.8 & 18.2 & 17.8 & 18.1 \\
\hline $56-65$ & 16.0 & 16.0 & 16.9 & 14.9 & 16.0 & 15.9 & 16.0 & 16.0 \\
\hline$>65$ & 22.7 & 21.9 & 25.1 & 21.1 & 22.6 & 22.6 & 22.7 & 22.7 \\
\hline \multicolumn{9}{|l|}{$\begin{array}{l}\text { Household's Monthly Net } \\
\text { Income }^{A}\end{array}$} \\
\hline Less than $£ / € 1000$ & 11.2 & 2.9 & 13.3 & 16.5 & 11.6 & 11.5 & 11.1 & 10.5 \\
\hline$£ / € 1001-£ / € 2000$ & 30.4 & 27.0 & 30.1 & 33.9 & 27.7 & 33.1 & 30.6 & 30.2 \\
\hline$£ / € 2001-£ / € 3000$ & 27.4 & 30.9 & 29.5 & 22.1 & 32.4 & 25.1 & 26.9 & 25.2 \\
\hline$£ / € 3001-£ / € 4000$ & 16.9 & 24.0 & 14.3 & 13.3 & 14.1 & 16.8 & 17.0 & 19.7 \\
\hline £/€4001 - £/€5000 & 7.9 & 8.8 & 8.8 & 6.2 & 7.3 & 7.6 & 7.6 & 9.3 \\
\hline$£ / € 5001-£ / € 6000$ & 3.7 & 5.0 & 2.5 & 3.8 & 4.3 & 3.3 & 4.3 & 3.0 \\
\hline More than £/€6000 & 2.4 & 1.4 & 1.5 & 4.3 & 2.6 & 2.5 & 2.5 & 2.2 \\
\hline Higher Education $^{\mathrm{B}}$ & 59.6 & 53.2 & 69.1 & 56.4 & 61.7 & 55.7 & 60.8 & 60.1 \\
\hline \multicolumn{9}{|l|}{ Employment Status } \\
\hline $\begin{array}{l}\text { Employed (full/part time or } \\
\text { self-employed) }\end{array}$ & 53.1 & 51.5 & 53.1 & 54.8 & 52.6 & 52.2 & 53.6 & 54.0 \\
\hline Unemployed & 13.0 & 13.4 & 9.1 & 16.7 & 12.1 & 15.2 & 12.1 & 12.8 \\
\hline Student & 4.8 & 5.7 & 5.1 & 3.5 & 5.9 & 4.5 & 3.9 & 4.8 \\
\hline Retired & 29.1 & 29.4 & 32.8 & 25.1 & 29.4 & 28.2 & 30.4 & 28.4 \\
\hline \multicolumn{9}{|l|}{ Household Size } \\
\hline 1 & 27.8 & 21.4 & 36.7 & 25.5 & 28.2 & 26.4 & 30.2 & 26.6 \\
\hline 2 & 41.2 & 43.6 & 42.1 & 37.9 & 39.8 & 42.2 & 40.5 & 42.3 \\
\hline 3 & 15.9 & 16.4 & 12.5 & 18.7 & 15.9 & 16.9 & 15.6 & 15.1 \\
\hline 4 & 10.3 & 12.3 & 6.4 & 12.1 & 11.1 & 8.7 & 9.6 & 11.7 \\
\hline 5 & 3.2 & 4.1 & 1.5 & 4.1 & 3.6 & 3.0 & 3.0 & 3.4 \\
\hline 6 or more & 1.6 & 2.1 & .8 & 1.7 & 1.6 & 2.7 & 1.1 & .9 \\
\hline $\mathbf{N}$ & 2,248 & 748 & 750 & 750 & 561 & 561 & 563 & 563 \\
\hline
\end{tabular}


Table A2: Overview of TPB Questions, Scales and Sources

\begin{tabular}{|c|c|c|c|}
\hline Construct & Items & Scale & Based on \\
\hline $\begin{array}{l}\text { Personal } \\
\text { Norm }\end{array}$ & $\begin{array}{l}\text { 1. I get a bad conscience if I throw away food. } \\
\text { 2. When I throw away food I feel guilty. }\end{array}$ & $\begin{array}{l}\text { 5-point Likert scale } \\
\text { strongly disagree - strongly agree }\end{array}$ & $\begin{array}{l}\text { Thøgersen, } 2006 \\
\text { Stefan et al., } 2013\end{array}$ \\
\hline $\begin{array}{l}\text { Subjective } \\
\text { Norm }\end{array}$ & $\begin{array}{l}\text { 1. I believe that most of my acquaintances (e.g. family, } \\
\text { friends, neighbors) expect that I try to reduce the } \\
\text { amount of food wasted in my household. } \\
\text { 2. I believe that most of my acquaintances try to reduce } \\
\text { the amount of food wasted in their households. }\end{array}$ & $\begin{array}{l}\text { 5-point Likert scale } \\
\text { strongly disagree - strongly agree }\end{array}$ & Thøgersen, 2006 \\
\hline Attitude & $\begin{array}{l}\text { 1. In my opinion reducing food waste is... } \\
\text { 2. In my opinion reducing food waste is... }\end{array}$ & $\begin{array}{l}\text { 7-point Likert scale } \\
\text { 1. not at all positive - extremely positive } \\
\text { 2. not at all important - extremely } \\
\text { important }\end{array}$ & Stancu et al., 2016 \\
\hline PBC & $\begin{array}{l}\text { 1. How much control do you have over reducing food } \\
\text { waste in your household? } \\
\text { 2. How difficult would it be for you to reduce food } \\
\text { waste at home? } \\
\text { 3. It is mostly up to me whether I reduce food waste in } \\
\text { my home. }\end{array}$ & $\begin{array}{l}\text { 5-point Likert scale } \\
\text { 1. very little control - great deal of control } \\
\text { 2. very difficult - very easy } \\
\text { 3. strongly disagree - strongly agree }\end{array}$ & Russell et al., 2017 \\
\hline Intention & $\begin{array}{l}\text { 1. I intend to reduce the amount of food I throw away. } \\
\text { 2. My goal is to reduce the amount of food I throw } \\
\text { away. } \\
\text { 3. I will try to reduce the amount of food I throw away. }\end{array}$ & $\begin{array}{l}\text { 7-point Likert scale } \\
\text { strongly disagree - strongly agree }\end{array}$ & Stancu et al., 2016 \\
\hline
\end{tabular}


Table A3: Overview of quiz questions and correct answers

\begin{tabular}{|c|c|c|}
\hline $\begin{array}{l}\text { Type of } \\
\text { knowledge }\end{array}$ & Question & Answers (correct answer in bold) \\
\hline \multirow[t]{3}{*}{ General } & $\begin{array}{l}\text { What percent of food is annually } \\
\text { wasted worldwide? }\end{array}$ & $\begin{array}{l}\text { a) } 10 \% \\
\text { b) } \mathbf{3 0 \%} \\
\text { c) } 50 \% \\
\text { d) } 85 \%\end{array}$ \\
\hline & $\begin{array}{l}\text { Which group of the food supply } \\
\text { chain causes most food waste and } \\
\text { loss in Europe? }\end{array}$ & $\begin{array}{l}\text { a) Food service (i.e. hotels, restaurants, } \\
\text { catering, canteens, hospitals) } \\
\text { b) Households } \\
\text { c) Processing (i.e. manufacturers of food } \\
\text { products and beverages) } \\
\text { d) Production (i.e. farmer, fisher, hunter) } \\
\text { e) Wholesale and retail }\end{array}$ \\
\hline & $\begin{array}{l}\text { Which types of food are wasted } \\
\text { the most in European households? }\end{array}$ & $\begin{array}{l}\text { a) Meat \& offal } \\
\text { b) Fish \& seafood } \\
\text { c) Roots \& tubers (e.g. potatoes, sweet } \\
\text { potatoes, cassava etc.) } \\
\text { d) Fruits \& vegetables } \\
\text { e) Cereals and cereal products (e.g. bread, } \\
\text { pastry, pasta, rice, maize, wheat etc.) } \\
\text { f) Milk \& eggs } \\
\text { g) Oilseeds \& pulses, incl. nuts (e.g. } \\
\text { soybeans, groundnuts (shelled), sunflower } \\
\text { seeds, olives, other oil crops) }\end{array}$ \\
\hline \multirow[t]{4}{*}{ System } & $\begin{array}{l}\text { The agricultural sector uses a } \\
\text { certain percentage fresh water for } \\
\text { the production of food that is later } \\
\text { on wasted. How much water is } \\
\text { used this way (compared to how } \\
\text { much agriculture uses in total)? }\end{array}$ & $\begin{array}{l}\text { a) } 1 \% \\
\text { b) } 5 \% \\
\text { c) } \mathbf{1 1 \%} \\
\text { d) } 15 \%\end{array}$ \\
\hline & $\begin{array}{l}\text { When food is wasted, this results } \\
\text { in } \mathrm{CO} 2 \text { emissions. The annual } \\
\mathrm{CO} 2 \text { emissions of household food } \\
\text { waste in Europe is as big as the } \\
\text { annual CO2 emissions of... }\end{array}$ & $\begin{array}{l}\text { a) approx. } 1 \text { million cars } \\
\text { b) approx. } 4 \text { million cars } \\
\text { c) approx. } 20 \text { million cars } \\
\text { d) approx. } \mathbf{4 0} \text { million cars }\end{array}$ \\
\hline & $\begin{array}{l}\text { What food, when wasted, } \\
\text { represents the biggest waste of } \\
\text { resources? }\end{array}$ & $\begin{array}{l}\text { a) Tomatoes } \\
\text { b) Beef } \\
\text { c) Poultry } \\
\text { d) Corn }\end{array}$ \\
\hline & $\begin{array}{l}\text { On average, what percentage of } \\
\text { value }(€) \text { of households' total } \\
\text { annual shopping basket goes to } \\
\text { waste in the } \\
\text { U.K./Germany/Belgium? }\end{array}$ & $\begin{array}{l}\text { a) } 6 \% \\
\text { b) } 12 \% \\
\text { c) } 18 \% \\
\text { d) } 24 \%\end{array}$ \\
\hline
\end{tabular}


More than 800 million people are currently undernourished. With all the food that is lost, discarded or wasted, we could feed...

a) One fourth of all undernourished people in the world ( \pm 200 million people)

b) Half of all undernourished people in the world ( \pm 400 million people)

c) Approx. all undernourished people in the world ( \pm 800 million people)

d) More than double the number of undernourished people in the world $(\sim 2$ billion people)

\begin{tabular}{|c|c|c|}
\hline \multirow[t]{5}{*}{$\begin{array}{l}\text { Action- } \\
\text { related }\end{array}$} & $\begin{array}{l}\text { What is the best place to store } \\
\text { bananas? }\end{array}$ & $\begin{array}{l}\text { a) At room temperature, e.g. in a bowl } \\
\text { b) In an air-tight plastic container } \\
\text { c) In the fridge } \\
\text { d) In a cool, dry place, e.g. in the basement }\end{array}$ \\
\hline & $\begin{array}{l}\text { What is the optimal temperature } \\
\text { of the fridge to keep food fresh } \\
\text { for the longest time? }\end{array}$ & (open answer) \\
\hline & $\begin{array}{l}\text { What does the "best before" date } \\
\text { on food packaging mean? }\end{array}$ & $\begin{array}{l}\text { a) After this date the food might not be at } \\
\text { its best but is still safe to eat if stored } \\
\text { according to storage instructions } \\
\text { b) After this date the food won't be safe to } \\
\text { eat. } \\
\text { c) This date is just for the shop staff, I ignore } \\
\text { it. } \\
\text { d) The food can be eaten without hesitation if } \\
\text { it is consumed no later than } 1 \text { week after } \\
\text { this date. }\end{array}$ \\
\hline & $\begin{array}{l}\text { What does the "use by" date on } \\
\text { food packaging mean? }\end{array}$ & $\begin{array}{l}\text { a) After this date the food might not be at its } \\
\text { best but is still safe to eat if stored } \\
\text { according to storage instructions } \\
\text { b) After this date the food won't be safe to } \\
\text { eat. } \\
\text { c) This date is just for the shop staff, I ignore } \\
\text { it. } \\
\text { d) The food can be eaten without hesitation if } \\
\text { it is consumed no later than } 1 \text { week after } \\
\text { this date. }\end{array}$ \\
\hline & $\begin{array}{l}\text { How can food waste at household } \\
\text { level be reduced? }\end{array}$ & $\begin{array}{l}\text { a) By writing a shopping list } \\
\text { b) By planning meals } \\
\text { c) By reusing leftovers } \\
\text { d) By composting at home }\end{array}$ \\
\hline
\end{tabular}

${ }^{\mathrm{A}}$ This question and the corresponding answers were adapted for each country. The numbers in the example are for Germany.

${ }^{\mathrm{B}}$ Multiple answers correct. 
Table A4: Results of the Confirmatory Factor Analysis

\begin{tabular}{|c|c|c|c|c|c|}
\hline Construct & Item & $\begin{array}{l}\text { Factor } \\
\text { loading }\end{array}$ & AVE & $\mathbf{C R}$ & $\begin{array}{l}\text { Cronbach's } \\
\text { Alpha }\end{array}$ \\
\hline \multirow[t]{2}{*}{ Personal Norm } & $\begin{array}{l}\text { When I throw away food I } \\
\text { feel guilty. }\end{array}$ & .888 & & & \\
\hline & $\begin{array}{l}\text { I get a bad conscience if I } \\
\text { throw away food. }\end{array}$ & .895 & .795 & .886 & .885 \\
\hline \multirow[t]{2}{*}{$\begin{array}{l}\text { Subjective } \\
\text { Norm }\end{array}$} & $\begin{array}{l}\text { I believe that most of my } \\
\text { acquaintances try to reduce } \\
\text { the amount of food wasted } \\
\text { in their households. }\end{array}$ & .667 & & & \\
\hline & $\begin{array}{l}\text { I believe that most of my } \\
\text { acquaintances (e.g. family, } \\
\text { friends, neighbors) expect } \\
\text { that I try to reduce the } \\
\text { amount of food wasted in } \\
\text { my household. }\end{array}$ & .738 & .495 & .661 & .657 \\
\hline \multirow[t]{2}{*}{ Attitude } & $\begin{array}{l}\text { In my opinion reducing } \\
\text { food waste is... (important) }\end{array}$ & .962 & & & \\
\hline & $\begin{array}{l}\text { In my opinion reducing } \\
\text { food waste is... (positive) }\end{array}$ & 699 & .707 & .825 & .793 \\
\hline \multirow[t]{2}{*}{ PBC } & $\begin{array}{l}\text { How much control do you } \\
\text { have over reducing food } \\
\text { waste in your household? }\end{array}$ & .860 & & & \\
\hline & $\begin{array}{l}\text { It is mostly up to me } \\
\text { whether I reduce food waste } \\
\text { in my home. }\end{array}$ & .711 & .623 & .766 & .751 \\
\hline \multirow[t]{3}{*}{ Intention } & $\begin{array}{l}\text { My goal is to reduce the } \\
\text { amount of food I throw } \\
\text { away. }\end{array}$ & .953 & & & \\
\hline & $\begin{array}{l}\text { I intend to reduce the } \\
\text { amount of food I throw } \\
\text { away. }\end{array}$ & .958 & & & \\
\hline & $\begin{array}{l}\text { I will try to reduce the } \\
\text { amount of food I throw } \\
\text { away. }\end{array}$ & .965 & .919 & .971 & .971 \\
\hline
\end{tabular}

$\mathrm{AVE}=$ Average Variance Extracted $\mathrm{CR}=$ Composite Reliability

The first model to be tested consisted of five latent variables (personal norm, subjective norm, attitude, PBC, and behavioral intention) and 12 manifest variables (i.e., the corresponding items measuring the five constructs). Despite a rather good model fit, reliability of the second item in the PBC scale ("How difficult would it be for you to reduce food waste at home?") 
and the latent variable PBC was not satisfactory. Due to the low factor loading of the PBC item on the PBC construct (standardized factor loading: .468), an insufficient Cronbach's Alpha for the PBC construct $(\alpha=.682$ ), and low values for average variance extracted (AVE) and composite reliability (CR), this item was excluded from further analysis. After having eliminated the item, confirmatory factor analysis was performed again. With the revised model, the value of Cronbach's Alpha increased and all scales had acceptable to high reliabilities.

Table A5: TPB Constructs - Means and results from ANOVA and post-hoc test for country specific distributions

\begin{tabular}{|c|c|c|c|c|c|}
\hline Construct & $\begin{array}{l}\text { Mean } \\
\text { Total }\end{array}$ & $\begin{array}{l}\text { Belgium } \\
(\mathrm{N}=748)\end{array}$ & $\begin{array}{l}\text { Germany } \\
(\mathrm{N}=750)\end{array}$ & $\begin{array}{l}\text { UK } \\
(\mathrm{N}=750)\end{array}$ & $\begin{array}{l}\text { ANOVA } \\
\text { (p-value) }\end{array}$ \\
\hline Personal Norm $^{A}$ & 3.94 & $3.84^{\mathrm{a}}$ & $4.12^{b}$ & $3.85^{\mathrm{a}}$ & .000 \\
\hline Subjective Norm $^{\mathrm{A}}$ & 2.42 & $2.39^{\mathrm{a}}$ & $2.45^{\mathrm{b}}$ & $2.41^{\mathrm{ab}}$ & .044 \\
\hline Attitude $^{B}$ & 5.98 & $5.86^{\mathrm{a}}$ & $6.17^{\mathrm{b}}$ & $5.90^{\mathrm{a}}$ & .000 \\
\hline $\mathbf{P B C}^{\mathbf{A}}$ & 3.72 & $3.56^{\mathrm{a}}$ & $3.87^{b}$ & $3.75^{\mathrm{c}}$ & .000 \\
\hline Intention $^{B}$ & 5.59 & $5.47^{\mathrm{a}}$ & $5.84^{b}$ & $5.45^{\mathrm{a}}$ & .000 \\
\hline
\end{tabular}

Table A6: Food Waste Knowledge - Percentage of average correct responses per knowledge dimension, ANOVA and post-hoc test for country specific distributions

\begin{tabular}{lccccr}
\hline $\begin{array}{l}\text { Questions (\% of respondents that } \\
\text { answered correctly) }\end{array}$ & Total & $\begin{array}{c}\text { Bel- } \\
\text { gium }\end{array}$ & $\begin{array}{c}\text { Ger- } \\
\text { many }\end{array}$ & UK & $\begin{array}{r}\text { ANOVA } \\
\text { (p-value) }\end{array}$ \\
\hline General Knowledge $(\mathrm{N}=2,248)$ & 33.64 & $31.60^{\mathrm{a}}$ & $36.76^{\mathrm{b}}$ & $32.58^{\mathrm{a}}$ & .000 \\
\hline System Knowledge $(\mathrm{N}=1,685)$ & 29.64 & 29.16 & 30.57 & 29.18 & .354 \\
\hline Action-related Knowledge $(\mathrm{N}=1,124)$ & 50.77 & 49.20 & 51.95 & 51.15 & .235 \\
\hline $\begin{array}{l}\text { ab Different letters in one row indicate significant differences between the respective groups. Evaluated by } \\
\text { Games-Howell post-hoc test. }\end{array}$
\end{tabular}


Table A7: Food Waste Knowledge - Percentage of average correct responses per knowledge dimension, ANOVA/t-test and post-hoc test for treatment specific distributions

\begin{tabular}{|c|c|c|c|c|c|}
\hline $\begin{array}{l}\text { Questions (\% of respondents that } \\
\text { answered correctly) }\end{array}$ & C1 & $\mathrm{C2}$ & T1 & $\mathbf{T 2}$ & $\begin{array}{r}\text { ANOVA/t- } \\
\text { test }(p-\text { value })\end{array}$ \\
\hline General Knowledge $(\mathrm{N}=2,248)$ & $33.81^{\mathrm{ab}}$ & $30.01^{\mathrm{a}}$ & $35.23^{b}$ & $35.52^{b}$ & .001 \\
\hline System Knowledge (N = 1,685) & $29.88^{\mathrm{ab}}$ & $31.37^{\mathrm{a}}$ & $27.67^{\mathrm{b}}$ & n.a. & .004 \\
\hline Action-related Knowledge $(\mathrm{N}=1,124)$ & n.a. & $55.47^{\mathrm{a}}$ & n.a. & $46.07^{\mathrm{b}}$ & .000 \\
\hline
\end{tabular}

Table A8: Selected Goodness-of-fit Statistics

\begin{tabular}{lll}
\hline Index of Fit & Value & $\begin{array}{l}\text { Requirement for Good Model Fit } \\
\text { (based on Schermelleh-Engel et al., 2003: 52) }\end{array}$ \\
\hline$\chi^{2}$ & $84.835(\mathrm{df}=34)$ & $0 \leq \chi^{2} \leq 2 \mathrm{df}$ \\
p-value & .000 & $.05<\mathrm{p} \leq 1.00$ \\
\hline RMSEA & .026 & $.00 \leq \mathrm{RMSEA} \leq .05$ \\
p-value & 1.000 & $.10<\mathrm{p} \leq 1.00$ \\
\hline$\chi^{2} /$ df & 2.495 & $0 \leq \chi^{2} / \mathrm{df} \leq 2$ \\
\hline SRMR & .0155 & $.00 \leq \mathrm{SRMR} \leq .05$ \\
\hline NFI & .995 & $.95 \leq \mathrm{NFI} \leq 1.00$ \\
\hline TLI & .995 & $.97 \leq \mathrm{TLI} \leq 1.00$ \\
\hline CFI & .997 & $.97 \leq \mathrm{CFI} \leq 1.00$
\end{tabular}

Table A9: Goodness-of-fit Indices for the Individual Groups

\begin{tabular}{lllccc}
\hline & $\chi^{2}(\mathbf{d f})$ & $\mathbf{p}$ & TLI & CFI & RMSEA \\
\hline C1 & $40.311(34)$ & .211 & .998 & .998 & .018 \\
\hline C2 & $82.289(34)$ & .000 & .981 & .988 & .050 \\
\hline T1 & $42.958(34)$ & .139 & .997 & .998 & .022 \\
\hline T2 & $75.845(34)$ & .000 & .984 & .990 & .047 \\
\hline
\end{tabular}


Table A10: Goodness-of-fit Indices for Configural and Metric Invariance Models

\begin{tabular}{llllll}
\hline & $\chi^{2}(\mathbf{d f})$ & $\mathbf{p}$ & TLI & CFI & RMSEA \\
\hline $\begin{array}{l}\text { Configural } \\
\text { Invariance }\end{array}$ & $241.404(136)$ & .000 & .990 & .994 & .019 \\
$\begin{array}{l}\text { Metric } \\
\text { Invariance }\end{array}$ & $260.181(154)$ & .000 & .991 & .994 & .018 \\
\hline
\end{tabular}

Table A11: Standardized (unstandardized) estimates of all groups and the full sample

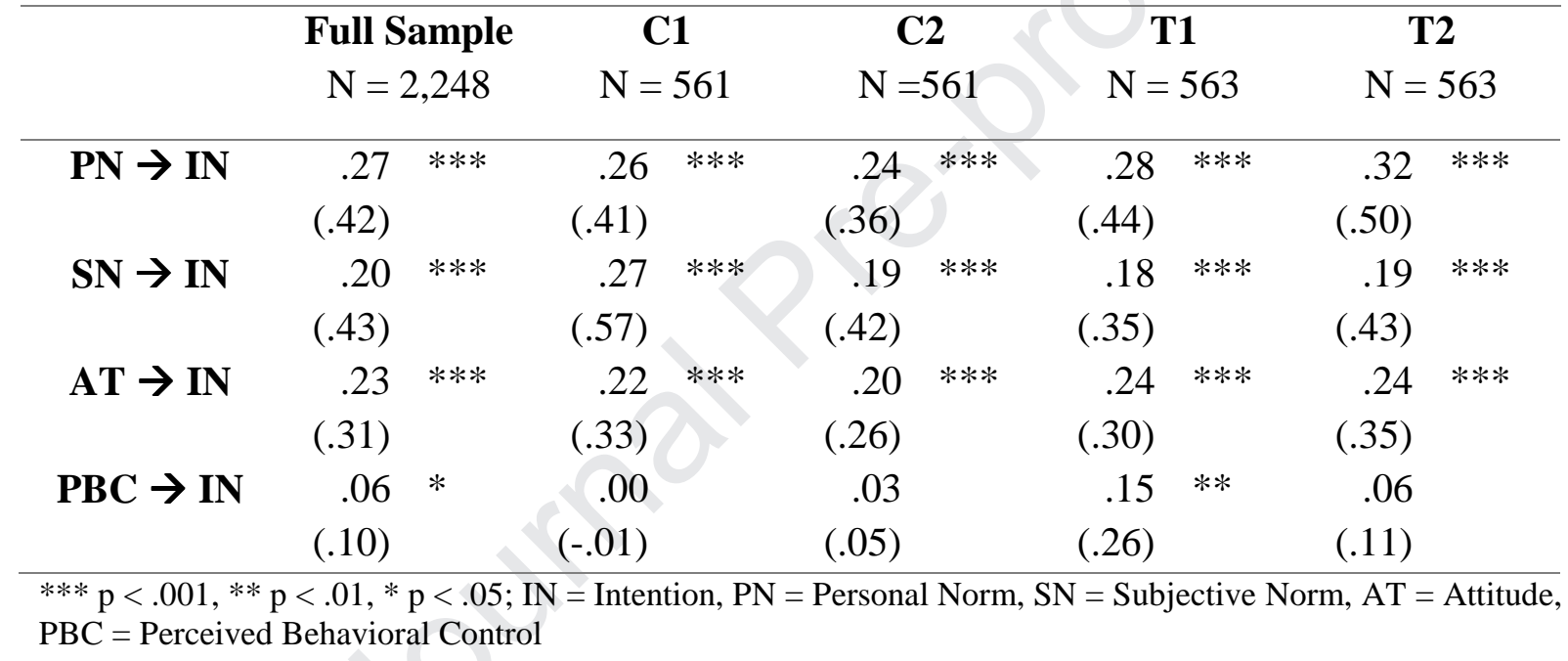

Table A12: p-values for group comparison of path coefficients

\begin{tabular}{lllllll}
\hline & C1 vs. C2 & C1 vs. T1 & C1 vs. T2 & C2 vs. T1 & C2 vs. T2 & T1 vs. T2 \\
\hline PN $\rightarrow$ IN & .680 & .785 & .452 & .490 & .234 & .635 \\
$\mathbf{S N} \rightarrow$ IN & .384 & .111 & .379 & .641 & .956 & .565 \\
$\mathbf{A T} \rightarrow$ IN & .501 & .786 & .861 & .654 & .394 & .646 \\
PBC $\rightarrow$ IN & .668 & .034 & .395 & .108 & .668 & .280
\end{tabular}

IN = Intention, $\mathrm{PN}=$ Personal Norm, $\mathrm{SN}=$ Subjective Norm, AT = Attitude, $\mathrm{PBC}=$ Perceived Behavioral Control; critical value of .008 (based on Bonferroni correction) was applied 


\section{Highlights}

- Providing information increases consumers' intention to reduce food waste

- Informing consumers about possible actions to reduce food waste is effective

- Informing consumers about food waste impacts is not effective in changing intention 


\section{Declaration of interests}

The authors declare that they have no known competing financial interests or personal relationships that could have appeared to influence the work reported in this paper.

囚The authors declare the following financial interests/personal relationships which may be considered as potential competing interests:

Funding: This work was supported by the European Institute of Innovation and Technology (EIT) through KIC Food [Project 18066 "Don't Be a Food Waster", 2018]. 